\title{
Biological indicative assessment of nematodes in evaluating different terrestrial habitats
}

\author{
Mohammad Asif ${ }^{1}$, Rehmat Jahan ${ }^{2}$ and Mohammad Mahboob ${ }^{2}$ \\ ${ }^{1}$ DDE, Maulana Azad National Urdu University, Hyderabad, Telangana, India \\ ${ }^{2}$ Section of Nematology, Department of Zoology, Aligarh Muslim University, Aligarh, Uttar Pradesh, India \\ Corresponding author e-mail: mohammadasif.nemato@gmail.com
}

(Received: 20/01/2021; Revised: 23/04/2021; Accepted: 15/06/2021)

\begin{abstract}
Healthy soil ecosystem plays crucial role maintaining global biosphere and developing sustainable agricultural practices. Land exploitation and improper agricultural practices greatly impact the soil health quality in time and space. Understanding the effects of organic and inorganic enrichments on soil quality and its indicators has been identified as one of the most important goals for modern soil science. For the present study, we compared the differences in the nematode diversity of healthy undisturbed soil with soil enriched with organic amendments and inorganic amendments. Soil samples were collected from three different habitats viz., organic enriched soil, inorganic enriched soil and undisturbed soil in rural and urban areas. Nematode community structure was studied in terms of frequency, density, biomass, trophic diversity and other common diversity or ecological indices. A total of 56, 61 and 72 nematode genera/species were identified in organic enriched, inorganic enriched and undisturbed soil. Shannon's diversity index $\left(\mathrm{H}^{\prime}\right)$ values were higher in undisturbed habitat than organic and inorganic enriched soil indicated that diversity of species was highest in undisturbed habitats. The Maturity index (MI), Structure Index (SI) was lowest and Enrichment Index (EI) was highest for organic and inorganic enriched soil revealed unstable and disturbed ecosystem. While in undisturbed habitats MI, SI were high and EI was lowest reflect stable and structured ecosystem. This study will provide a base for stakeholders mainly in land use and sustainable agricultural practices and serves as a triggering mechanism for implementation of soil contamination mitigating strategies.
\end{abstract}

Keywords: Bioindicator; Diversity indices; Enriched soil; Nematode community; Soil quality; Trophic group.

\section{INTRODUCTION}

Twenty first century main concern is the impact of anthropogenic activities such as industrialization, urbanization and extensive agricultural practice using inorganic fertilizers and pesticide. Agents that affect soil health are added to the soils by various anthropogenic activities can build up to concentrations that build and change microbial biota and eventually affects the plant and animal health (Alloway, 1995). The nematode community analyses upto species level reveals insight into the environmental ecosystem structure and function where a larger and more diverse assemblages reflect a capacity to perform ecological functions and thus sustain soil productivity and health (Yeates, 1997). Functional or trophic groups of nematodes can be explained as groups of species that have similar kinds of effects on ecosystem processes such as anthropogenic disturbance (Chapin et al., 1992). A change in their community composition in the soil food web reflects changes in environmental conditions (Bongers and Ferris 1999, Wasilewska, 1994; Thornton and Matlack 2002; Wall et al., 2002). The ecologists generally recognize the following five major trophic groups among soil inhabiting nematodes based on the nature of their feeding habit and structure of feeding apparatus viz., Bacteriovores, Fungivores, Herbivores, Omnivores and predators (Yeates et al., 1993; Yeates, 1998; Yeates and Bongers, 1999). Nematodes viewed as indicators of soil ecosystem resilience due to the presence of these multiple trophic participating in soil food webs and play important role in nutrient recycling. Their diverse life history strategies may indicate whether the ecosystem has experienced a recent disturbance e.g. large-bodied omnivores and predators are persistent k-strategists, whereas bacterivores and fungivores are smaller, more numerous and respond to environmental perturbations as r-strategists (Bongers and Bongers, 1998). Bacterivores in the families Rhabditidae and Cephalobidae reflect changes in soil ecological functions due to the tendency of the Rhabditidae to increase following nutrient inputs, while the ubiquitous Cephalobidae increase in abundance during primary and secondary succession (Yeates, 2003). Use of mainly inorganic ammendments in agricultural land causes soil ecosystem dsturbnce and reflected by different communities of microorganisms residing in the soil (Fließbach and Mäder, 2000; Yeates, 2003; Giola et al., 2012; Oloyede, 2012; Liu et al., 2013; Khan et al., 2014). 
Soil nematodes, as a major mesofauna of soil food webs provides a wide range of ecosystem services including organic material decomposition, cycling of mineral nutrients, regulation of pest species and energy of transfer (Hättenschwiler et al., 2005; Wall et al., 2012; Coleman and Wall, 2015). Indeed, nematodes communities provides information on changes in different decomposition pathways in the soil food web, nutrient status, fertility and acidity of the soil and the effect of pollutants in the soil ecosystem (Hohberg 2003; Elmer et al., 2013; Li et al., 2016; Franco et al., 2017; Bokhorst et al., 2017.

Ecological indices of nematode assemblages used to describe changes in soil ecological functions are: (1) maturity index (MI) to assess the free-living nematodes response to stress, where higher values represent a more stable community (Neher, 2010), (2) Enrichment index (EI) to indicate the availability of food resources and measure the increase in small-bodied opportunistic bacterial and fungal feeders that respond quickly to $\mathrm{C}$ and $\mathrm{N}$ inputs, and (3) Structure index (SI), where higher values suggest more linkages in the food web and greater soil resilience (Ferris et al., 2001). Soil monitoring using nematodes is feasible, less expensive method for study of regional variations and the anthropogenic contamination that destruct the soil health such various toxic organic and inorganic compounds and heavy metals in soil. Bio monitoring provides a direct measure of biological effect rather than inferring values using expensive soil extractions (Tarazona et al., 2005). The information generated by studying nematode community structure proved to be greatly useful for the conservation, monitoring and remediation processes of ecosystem (Stone et al., 2016). It will help the stakeholders for environmental planning and monitoring in rural and urban area. Based on holistic nematode community analysis of different habitats the highest risk sites can be identified in which the remediation activity and monitoring should take place. The major objective of the present study was the biomonitoring of soil quality of selected habitats in rural and urban areas in various district of Uttar Pradesh. Nematode community analysis provides feasible method for assessing and mapping soil quality changes in time and space in small units.

\section{MATERIALS AND METHODS}

Site description, soil sampling and nematode extraction The samples were randomly collected from soil enriched with organic amendments (soil with organic decomposing matter), inorganic industrial effluents and inorganic fertilizers used in agricultural fields and from healthy undisturbed soil ecosystemfrom different districts of the Western Uttar Pradesh, which forms the fifth largest and most populous state of India's. It includes highly fertile Rohilkhand plain, upper, middle and part of lower Ganga-Yamuna doab region. The region holds distinction from other parts of the country in its demographic, economic and cultural patterns It falls within the coordinates $29^{\circ} 58^{\prime} 12^{\prime \prime} \mathrm{N}$ to $26^{\circ} 28^{\prime} 12^{\prime \prime}$
$\mathrm{N}$ along the latitude and $77^{\circ} 35^{\prime} 0^{\prime \prime} \mathrm{E}$ to $80^{\circ} 6^{\prime} 0^{\prime \prime} \mathrm{E}$ along the longitude.

\section{Sampling sites}

1. Soil samples were randomly collected from different three habitats that are rich in organic manure, dead and decaying plant material or leaf litter, compost, dung, rotten wood, tree holes in year, from 2016-18.

2. Soil collected from nearby drains from local industries paper industries, metal industries and dyes industries that contain inorganic compounds/chemicals as effluents. And also form fields that are treated with inorganic nitrogen fertilizer only; inorganic nitrogen, phosphorus and potassium fertilizers; and organic fertilizer plus inorganic nitrogen, phosphorus and potassium fertilizers. 3. Soil samples collected from natural undisturbed habitat like forest patches located in the region.

Sixty samples collected from each habitat making 180 soil samples and each sample represented a thoroughly mixed composite sample of three replicate sub-samples which makes total 540 samples. The samples were collected by digging out soil from pit of $5 \mathrm{~cm}$ diameter and $20 \mathrm{~cm}$ depth and were stored in sealed plastic bags brought to laboratory for further processing. The samples were processed by modified Cobb's (1918) sieving, decantation and modified Baerman's funnel technique for isolation of nematodes.

Nematode identification, counting, community analysis and diversity indices

The freshly extracted nematodes were examined under stereoscopic microscope (BX-41) and mass slides containing one hundred nematodes per sample were prepared for identification at the generic level. Identification up to generic level was done mainly using Goodey (1963); Jairajpuri and Khan (1982); Andrássy (1984), Siddiqi (1986), Jairajpuri and Ahmad (1992); Ahmad (1996). Trophic group and cp values were allocated according to Yeates et al. (1993).

Identification at species level were done by studying their permanent mounts after fixation by $\mathrm{F}$ :A fixation and dehydration in glycerine alcohol (95 parts of $30 \%$ alcohol +5 parts of glycerol). Counting of each sample was done thrice and mean was obtained. The individual species population and the total count of nematode were used for calculation of various indices. The basic statistical parameters viz., frequency, relative frequency, density, relative density, mean biomass (Andrássy, 1956) and relative biomass (Norton, 1978), the various diversity and food web indices were calculated.

\section{The following parameters were used:}

Frequency $(\mathrm{N})$ : Frequency of nematode genus (i.e., the number of samples in which the genus was present).

Absolute frequency (AF\%): (Frequency of the genus) $\times$ 100/total number of samples collected

Density (MD): Number of nematode specimens of the genus counted in all samples/total number of the samples collected.

Relative density (RD\%): Mean density of the genus $\times$ $100 /$ sum of mean density of all nematode genera. 
Mean biomass (MB) $\mu \mathrm{g}$ : (Biomass of one nematode individual of the genus) $\times$ (absolute density of the genus).

Relative biomass (RMB) $\mu \mathrm{g}$ : (Mean biomass of the genus) $\times(100)$ /sum of biomass of all genera).

The following indices were calculated:

Shannon's diversity $\left(\mathrm{H}^{\prime}\right)=-\Sigma(p i \ln p i)$

Maturity Index (MI)

$M I=\sum_{i=1}^{n} V i(i) \cdot f(i)$

Where $\mathrm{Vi}=\mathrm{cp}$ value of the ith taxon.

$\mathrm{f}(\mathrm{i})$ the frequency of that taxon in a sample

* Maturity index (MI) is calculated as the weighted mean of the individual cp value.

Plant Parasitic index (PPI)

$P P I=\Sigma P P i X i / \Sigma X i$

Where, $\mathrm{PPi}=\mathrm{PP}$ value assigned to taxon $\mathrm{i}$ according to Bongers (1990).

$\mathrm{Xi}=$ abundance of taxon $\mathrm{i}$ in the sample.

Nematode Channel Ratio (NCR)

$\mathrm{NCR}=\mathrm{B} / \mathrm{B}+\mathrm{F}$

Where, $\mathrm{B}=$ Total abundance of Bacterial feeding nematodes

$\mathrm{F}=$ Total abundance of Fungal feeding nematodes.

Trophic Diversity index $(\mathrm{TDI})=1 / \Sigma \mathrm{pi}^{2}$

where pi is the proportional contribution of ith trophic group.

Basal Index $=100 \mathrm{xb} / \mathrm{b}+\mathrm{s}+\mathrm{e}$

Enrichment Index $(\mathrm{EI})=100 \times e /(e+b)$.

Structure Index (SI) $=100 \mathrm{x} s /(s+b)$.

where $e, b$ and $s$ are sum products of assigned weights and abundance of individuals in the corresponding $c-p$ classes.

\section{RESULTS AND DISCUSSION Organic enriched habitats \\ Diversity and abundance}

A total of fifty-six nematode species belonging to 10 orders and 30 families were identified. A minimum of ten and a maximum of eighteen species per sample were recorded, with most of the samples containing ten-fifteen species. In terms of individual abundance, the numbers of nematodes in a sample ranged from 350-1842 individuals with mean a value of $1296.93 \pm 148.36$ per $100 \mathrm{cc}$ of soil. In terms of taxonomic groups (Table.2: Fig.1. AandB), Order Rhabditida was found to be the most prevalent (46\%) followed Dorylaimida (21\%), Tylenchida (9\%), Plectida (7\%), Aphelenchida and Mononchida with (4\% each), Enoplida (3\%), Chromodorida, Monhysterida and Triplonchida with ( $2 \%$ each) occurrence rate. In terms of abundance also, Order Rhabditida was most dominant group (55\%), followed by Dorylaimida (19\%), Tylenchida (9\%), Plectida (6\%), Enoplida and Mononchida (3\% each), Aphelenchida (2\%), Chromodorida, Monhysterida and Triplonchida with (1\% each) occurrence rate (Fig.1. AB).

\section{Trophic groups}

The trophic structure of the organic enriched habitats represented by the nematode categories of bacterivores, carnivores (predators), herbivores, omnivores and fungivores. Of the different trophic groups the bacteriovores representing the highest number $(50 \%)$ followed by predators (23\%), fungivores (11\%), herbivores (9\%) and omnivores shows the least (7\%) occurrence rate. In terms of individual abundance too, bacteriovores constituted the most dominant group (54\%) followed by predators (18\%), fungivores $(12 \%)$. Representation of herbivores and omnivores were the least with (8\% each) occurrence rate (Fig.2. A-B).

\section{Frequency}

Among bacteriovores, the highest frequency was recorded for Chiloplacus subtenuis $(\mathrm{N}=44)$ with an absolute frequency of $73.33 \%$. The species Neotylocephalus annonae was the least frequent $(\mathrm{N}=4)$ with $\mathrm{AF}=6.67 \%$. Among predators, the species Aporcelaimellus tropicus was the most prevalent $(\mathrm{N}$ $=20$ ) with absolute frequency (AF) of $33.33 \%$, whereas the least frequent species was Myctolaimus sp. with $(\mathrm{N}=2)$ and $\mathrm{AF}=3.33 \%$. Aphelenchus avenae was the most frequent species among fungivores representing $(\mathrm{N}$ $=28$ ) with absolute frequency (AF) of $46.67 \%$ while the Leptonchus baccatus $(\mathrm{N}=7)$ was the least frequent species among fungivores with $\mathrm{AF}=11.67 \%$. Among plant parasitic or herbivores, Helicotylenchus dihystera was the most prevalent with $(\mathrm{N}=20)$ and $\mathrm{AF}=33.33 \%$. The least occurring was Tylenchus arcuatus with $(\mathrm{N}=5)$ and $\mathrm{AF}=8.33 \%$. The species Mesodorylaimus subtiloides $(\mathrm{N}=16)$ and $\mathrm{AF}=26.67 \%$ occurred frequently among omnivores whereas Thornenema mauritianum $(\mathrm{N}=4)$ and $\mathrm{AF}=6.66 \%$ was the least frequent among omnivores (Table 1).

Density

Acrobeloides nanus was the most dominant species (MD $=58.87$ ) among bacteriovores, with relative density of $8.54 \%$. The least dominant species were Tylocephalus sp. $(\mathrm{MD}=1.99)$ with relative density of $0.29 \%$, Neotylocephalus annonae $(\mathrm{MD}=0.99)$ with relative density of $0.14 \%$. Discolaimus major $(\mathrm{MD}=19.26)$ dominated among predators with relative density of $2.79 \%$ while Neoactinolaimus agilis $(\mathrm{MD}=0.65)$ with relative density of $0.09 \%$ was the least among the group. Among fungivores, Aphelenchus avenae $(\mathrm{MD}=30.05)$ dominated the group with relative density of $4.36 \%$ whereas the representation of Leptonchus baccatus (MD $=1.99$ ) was the least with relative density of $0.29 \%$. Helicotylenchus dihystera $(\mathrm{MD}=14.01)$ was the dominated among herbivores with relative density of $2.03 \%$ while Tylenchus arcuatus $(\mathrm{MD}=1.86$ ) was the least occured with relative density of $0.27 \%$. Among omnivores Mesodorylaimus subtiloides $(\mathrm{MD}=9.98)$ dominated the omnivores group with relative density of $1.45 \%$ and Thornenema mauritianum $(\mathrm{MD}=1.35$ ) least frequent with relative density of $0.20 \%$ (Table 1 ). 
Table 1. Population structure of soil inhabiting nematodes genera/species in organic enriched environment.

\section{Genera/species \\ BACTERIOVORES}

Achromadora indica

Anaplectus granulosus

Acrobeles complexus

Acrobeloides nanus

Alaimus primitivus

Caenorhabditis brenneri

Cephaloboides curvicaudatus

Cephaloboides anisospiculus

Cephalobus persegnis

Cervidellus vexilliger

Chiloplacus subtenuis

Diploscapter coronatus

Eucephalobus oxyuroides

Mesorhabditis cranganorensis

Metarhabditis amsactae

Monhystera paludicola

Neotylocephalus annonae

Oscheius shamimi

Panagrolaimus filiformis

Panagrolaimus rigidus

Plectus parvus

Poikilolaimus oxycercus

Protorhabditis oxyuroides

Rhabditis terricola

Teratorhabditis synpapillata

Teratorhabditis andrassyi

Tylocephalus palmatus

Zeldia punctata

Sum

Mean

SD

\section{FUNGIVORES}

Aphelenchoides composticola

Aphelenchus avenae

Basirotyleptus basiri

Filenchus microdorus

Leptonchus baccatus

Tylencholaimellus striatus

Sum

Mean

SD

\section{HERBIVORES}

Helicotylenchus dihystera

Hoplolaimus indicus

Longidorous elongatus

Tylenchorhynchus mashhoodi

Tylenchus arcuatus

Sum

Mean

SD

OMNIVORES

Eudorylaimus silvaticus

Microdorylaimus parvus

Mesodorylaimus subtiloides

$$
\text { N AF\% }
$$

14.00

5.00

38.00

42.00

6.00

21.00

25.00

18.00

32.00

16.00

44.00

18.00

20.00

30.00

25.00

8.00

4.00

18.00

35.00

28.00

14.00

15.00

15.00

26.00

25.00

18.00

5.00

8.00

573.00

20.46

11.17

21.00

28.00

11.00

15.00

7.00

14.00

96.00

16.00

7.48

$$
23.33
$$

8.33

63.33

70.00

10.00

35.00

41.67

30.00

53.33

26.67

73.33

30.00

33.33

50.00

41.67

13.33

6.67

30.00

58.33

46.67

23.33

25.00

25.00

43.33

41.67

30.00

8.33

13.33

955.00

34.11

18.61

35.00

46.67

18.33

25.00

11.67

23.33

160.00

26.67

12.47

$20 \quad 33.33$

$\begin{array}{ll}16 & 26.67\end{array}$

$8 \quad 13.33$

12

5

61

12.2

6.02

20.00

8.33

101.67

20.33

10.03

12.00

8.00

20

16.00
MD

RD\%

MB

RMB \%

9.45

1.34

28.14

58.87

3.26

11.37

13.76

11.05

38.95

18.95

37.07

25.99

26.76

40.65

12.32

$-7.99$

0.99

11.49

16.79

13.26

16.56

8.11

6.15

10.81

7.99

6.90

1.99

4.45

451.40

16.12

13.95

18.85

30.05

6.59

14.34

1.99

8.85

80.67

13.45

10.05

14.01

9.56

3.47

6.99

1.86

35.89

7.178

4.86

6.55

5.46

9.98

\subsection{7}

15.39

0.89

$\begin{array}{lll}0.19 & 20.90 & 1.21\end{array}$

$\begin{array}{lll}4.08 & 20.43 & 1.19\end{array}$

$\begin{array}{lll}8.54 & 21.86 & 1.27\end{array}$

$\begin{array}{lll}0.47 & 15.32 & 0.89\end{array}$

$\begin{array}{lll}1.65 & 19.16 & 1.11\end{array}$

$\begin{array}{lll}2.00 & 20.14 & 1.17\end{array}$

$\begin{array}{lll}1.60 & 24.31 & 1.41\end{array}$

$\begin{array}{lll}5.65 & 25.56 & 1.48\end{array}$

$\begin{array}{lll}2.75 & 6.39 & 0.37\end{array}$

$\begin{array}{lll}5.38 & 20.22 & 1.17\end{array}$

$\begin{array}{lll}3.77 & 7.79 & 0.45\end{array}$

$\begin{array}{lll}3.88 & 20.07 & 1.16\end{array}$

$\begin{array}{lll}5.90 & 28.45 & 1.65\end{array}$

$\begin{array}{lll}1.79 & 21.28 & 1.24\end{array}$

$\begin{array}{lll}1.16 & 26.367 & 1.53\end{array}$

$\begin{array}{lll}0.14 & 0.89 & 0.05\end{array}$

$\begin{array}{lll}0.67 & 28.34 & 1.64\end{array}$

$\begin{array}{lll}2.44 & 11.80 & 0.68\end{array}$

$\begin{array}{lll}1.92 & 13.92 & 0.81\end{array}$

$\begin{array}{lll}2.40 & 10.64 & 0.62\end{array}$

$\begin{array}{lll}1.18 & 41.52 & 2.41\end{array}$

$\begin{array}{lll}0.89 & 1.96 & 0.11\end{array}$

$\begin{array}{lll}1.57 & 19.45 & 1.13\end{array}$

$\begin{array}{lll}1.16 & 28.38 & 1.65\end{array}$

$\begin{array}{lll}1.00 & 31.05 & 1.80\end{array}$

$\begin{array}{lll}0.29 & 1.19 & 0.07\end{array}$

$\begin{array}{lll}0.65 & 21.69 & 1.26\end{array}$

65.50

2.34

2.02

524.57

18.73

9.55

30.44

1.09

0.55

$\begin{array}{rrr}2.74 & 3.77 & 0.22 \\ 4.36 & 5.15 & 0.30 \\ 0.96 & 8.27 & 0.48 \\ 2.08 & 3.44 & 0.20 \\ 0.29 & 10.92 & 0.63 \\ 1.28 & 15.93 & 0.92 \\ 11.70 & 47.48 & 2.76 \\ 1.95 & 7.91 & 0.46 \\ 1.46 & 4.86 & 0.28\end{array}$

2.03

12.19

0.71

1.39

57.72

155.37

3.35

0.50

1.01

0.27

5.21

13.63

9.02

0.79

14.28

0.83

1.04

253.19

14.69

0.70

50.64

2.94

61.62

3.58

0.95

104.47

6.06

0.79

16.79

0.97

1.80 


$\begin{array}{lcccccc}\text { Thornenema mauritianum } & 4.00 & 6.66 & 1.35 & 0.20 & 20.86 & 1.21 \\ \text { Sum } & 40.00 & 66.67 & 23.34 & 3.39 & 173.18 & 10.05 \\ \text { Mean } & 10.00 & 16.67 & 5.84 & 0.85 & 43.30 & 2.51 \\ \text { SD } & 5.16 & 8.61 & 3.56 & 0.52 & 41.22 & 2.39 \\ \text { PREDATORS } & & & & & & \\ \text { Aporcelaimellus tropicus } & 20.00 & 33.33 & 16.50 & 2.39 & 120.29 & 6.98 \\ \text { Butlerius butleri } & 5.00 & 8.33 & 2.21 & 0.32 & 20.42 & 1.18 \\ \text { Discolaimoides bulberiferus } & 9.00 & 15.00 & 3.33 & 0.48 & 21.09 & 1.22 \\ \text { Discolaimus major } & 18.00 & 30.00 & 19.26 & 2.79 & 193.24 & 11.21 \\ \text { Ironus dentifurcatus } & 15.00 & 25.00 & 17.45 & 2.53 & 82.36 & 4.78 \\ \text { Laimydorus papillatus } & 7.00 & 11.67 & 2.14 & 0.31 & 19.81 & 1.15 \\ \text { Mononchoides fortidens } & 12.00 & 20.00 & 9.56 & 1.39 & 79.83 & 4.63 \\ \text { Mononchoides composticola } & 16.00 & 26.67 & 10.13 & 1.47 & 26.21 & 1.52 \\ \text { Mylonchulus hawaiiensis } & 12.00 & 20.00 & 6.99 & 1.01 & 47.53 & 2.76 \\ \text { Neoactinolaimus agilis } & 4.00 & 6.67 & 0.65 & 0.09 & 24.38 & 1.41 \\ \text { Oigolaimella longicauda } & 6.00 & 10.00 & 3.14 & 0.46 & 31.09 & 1.80 \\ \text { Myctolaimus sp. } & 2.00 & 3.33 & 1.51 & 0.22 & 51.64 & 3.00 \\ \text { Tripyla glomerans } & 13.00 & 21.67 & 4.46 & 0.65 & 7.00 & 0.41 \\ \text { Sum } & 139.00 & 231.67 & 97.33 & 14.12 & 724.88 & 42.06 \\ \text { Mean } & 10.69 & 17.82 & 7.49 & 1.09 & 55.76 & 3.24 \\ \text { SD } & 5.68 & 9.46 & 6.55 & 0.95 & 52.46 & 3.04\end{array}$

cp scale - Allocation of values on colonizer-persistor scale (Bongers, 1990).

$\mathrm{N}$, frequency; $\mathrm{AF}$, absolute frequency; $\mathrm{MD}$, density; $\mathrm{RD}$, relative density; $\mathrm{MB}$, mean biomass; $\mathrm{RMB}$, relative biomass.

\section{Mean Biomass}

The data of the enriched habitats revealed that the biomass of bacteriovores to be the greatest) among all groups i.e., $50 \%$, followed by Predators (43\%), fungivores $(3 \%)$. omnivores and herbivores $(2 \%)$ each. Teratorhabditis andrassyi constituted the highest biomass among bacteriovores, with a mean value of $31.05 \mu \mathrm{g}$ and relative mean biomass of $1.80 \%$. The least biomass was recorded for Neotylocephalus annonae $(0.89 \mu \mathrm{g})$, with relative mean biomass of $0.05 \%$. Among predators, the species Discolaimus major being the large sized and, having a comparatively high density, had the highest mean biomass $(193.23 \mu \mathrm{g})$ and relative mean biomass of $11.21 \%$ while Tripyla glomerans due to its small size showed the lowest mean biomass $(7.00 \mu \mathrm{g})$ and relative mean biomass of $0.41 \%$. Among fungal feeding nematodes, Tylencholaimellus striatus, constituted the highest mean biomass $(15.93 \mu \mathrm{g})$ and had a relative mean biomass of $0.92 \%$. While, Filenchus microdorus $(3.19 \mu \mathrm{g}, \mathrm{RMB}=0.20)$ had the least mean biomass in this group. Although Helicotylenchus dihystera was the most dominant species in the herbivore group, Longidorous elongatus being large-sized, had the highest mean biomass $(155.37 \mu \mathrm{g})$ and a relative mean biomass of $9.02 \%$. Helicotylenchus dihystera due to its small size had the least mean biomass $(12.19 \mu \mathrm{g})$ with a relative mean biomass of $0.71 \%$. The species Eudorylaimus silvaticus due to its large sized showed a comparatively high density, had the highest mean biomass $(104.47 \mu \mathrm{g})$ and relative mean biomass of $6.06 \%$ in the omnivore group, while the species Microdorylaimus parvus due to its small body size $(16.79 \mu \mathrm{g}, \mathrm{RMB}=0.97)$ had the least mean biomass (Table 1).

\section{Inorganic enriched habitats}

Diversity and abundance

A total of sixty-one nematode species belonging to 10 orders and 33 families were identified. A minimum of ten and a maximum of twenty species per sample were recorded, with most of the samples containing ten-fifteen genera. In terms of individual abundance, the numbers of nematodes in a sample ranged from 458-1242 specimens with mean a value of $896.93 \pm 248.36$ per $100 \mathrm{cc}$ of soil. In terms of taxonomic groups, order Rhabditida was found to be the most prevalent (36\%) followed Dorylaimida (17\%), Tylenchida (15\%), Plectida (10\%), Monhysterida and Triplonchida with (5\% each), Aphelenchida, Chromodorida, Enoplida and Mononchida with (3\% each) occurrence rate. In terms of abundance also, Order Rhabditida was most dominant group $(42 \%)$, followed by Dorylaimida (18\%), Tylenchida (16\%), Plectida (9\%), Monhysterida, Triplonchida and Mononchida (3\% each), Aphelenchida (2\%), Chromodorida and Enoplida with (2\% each) occurrence rate (Fig.1. C-D). 
Figure 1. Ordinal Diversity
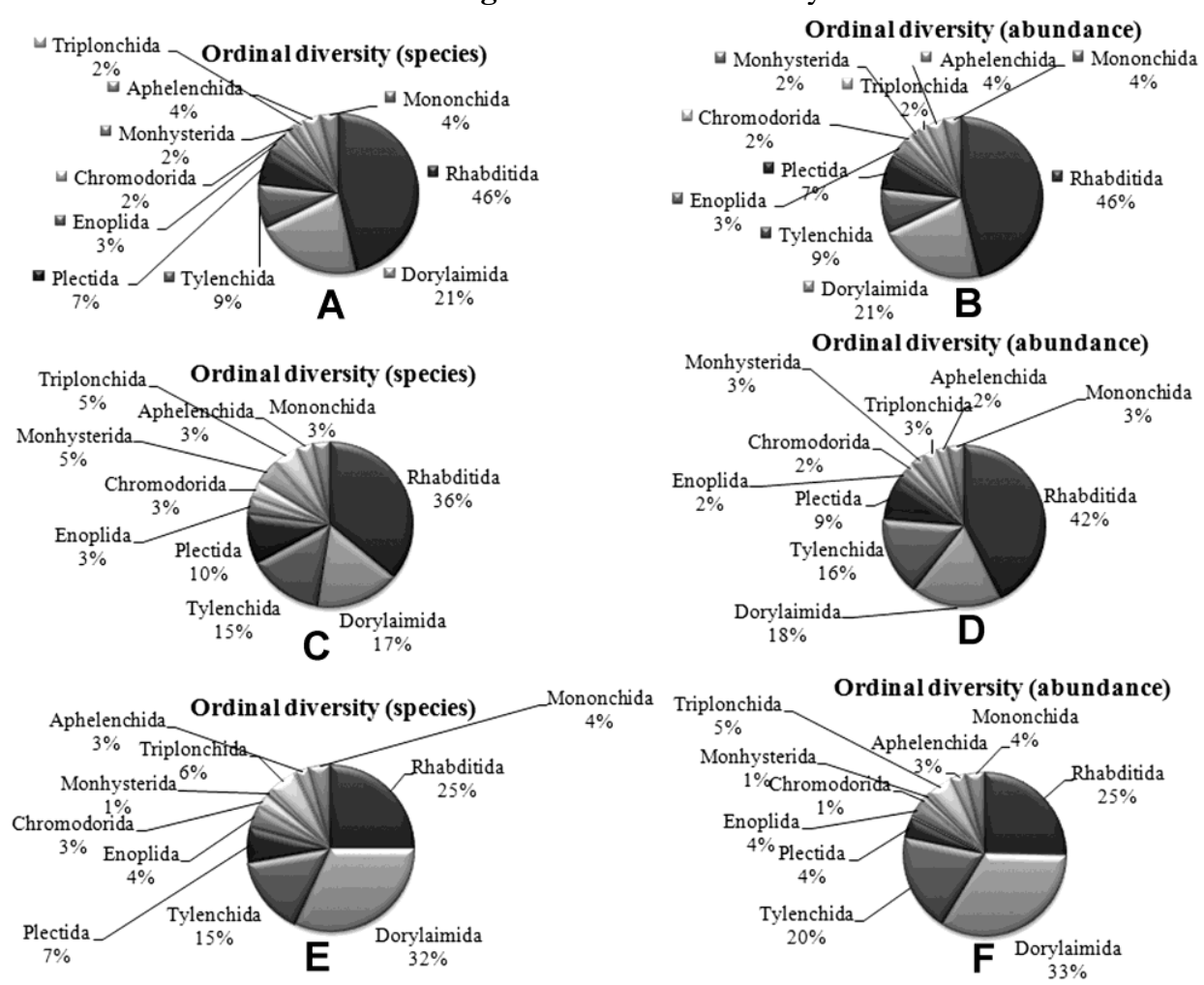

*Ordinal diversity of soil inhabiting nematodes in A-B: Organic enriched habitats; C-D: Inorganic enriched habitats; E-F: undisturbed habitats.

Figure 2. Trophic Diversity

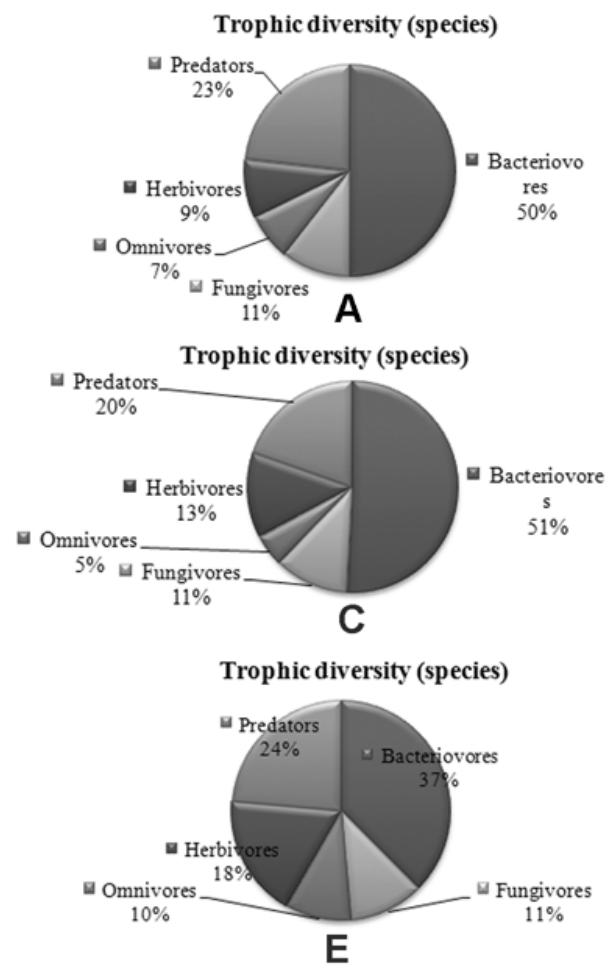

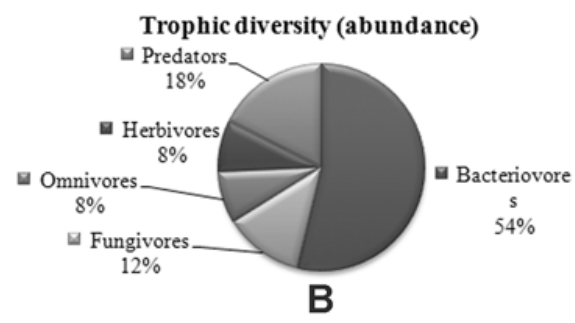

Trophic diversity (abundance)
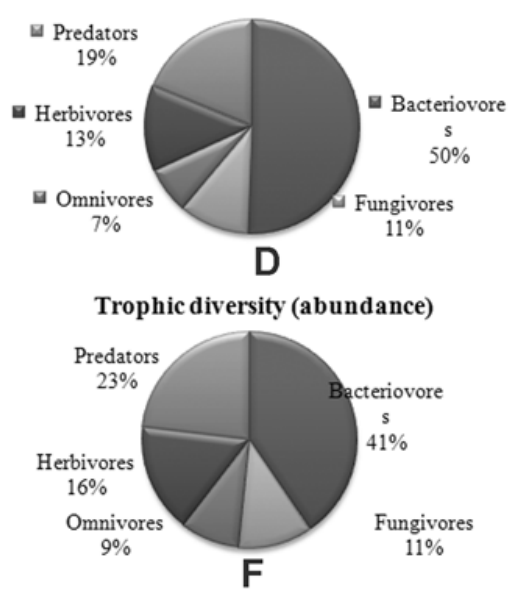

*Trophic diversity of soil inhabiting nematodes in A-B: Organic enriched habitats; C-D: Inorganic enriched habitats; E-F: undisturbed habitats. 


\section{Trophic groups}

The trophic structure of the inorganic enriched habitats represented by the nematode categories of bacterivores, carnivores (predators), herbivores, omnivores and fungivores. Of the different trophic groups, the bacteriovores represented the highest number of species (51\%) followed by predators $(20 \%)$, herbivores (13\%), fungivores $(11 \%)$, and omnivores were the least with $(5 \%)$ occurrence rate. In terms of individual abundance too, bacteriovores constituted the most dominant group $(50 \%)$ followed by predators $(19 \%)$, herbivores $(13 \%)$ Representation of fungivores $(11 \%)$ and omnivores were the least with (7\%) occurrence rate (Fig.2. C-D).

\section{Frequency}

Among bacteriovores, the highest frequency was recorded for Cephalobus parvus $(\mathrm{N}=40)$ with an absolute frequency of $66.67 \%$. The species Ceratoplectus armatus was the least frequent $(\mathrm{N}=4)$ with $\mathrm{AF}=6.33 \%$. Among predators, the species Discolaimus similis was the most prevalent $(\mathrm{N}=20)$ with absolute frequency (AF) of $33.33 \%$, whereas the least frequent species were Fictor vorax and Paractinolaimus macrolaimus with $(\mathrm{N}=5)$ and $\mathrm{AF}=8.33 \%$. Aphelenchoides composticola was the most frequent species among fungivores representing $(\mathrm{N}=22)$ with absolute frequency (AF) of $36.67 \%$ while the Tyleptus projectus $(\mathrm{N}=6)$ was the least frequent species among fungivores with $\mathrm{AF}=10 \%$. Among plant parasitic or herbivores species Hemicriconemoides magniferae was the most prevalent with $(\mathrm{N}=28)$ and $\mathrm{AF}=46.67 \%$. The least occurring was Longidorus brevicaudatus with $(\mathrm{N}=$ $5)$ and $\mathrm{AF}=8.33 \%$. The species Moshajia idiophora $(\mathrm{N}$ $=18$ ) and $\mathrm{AF}=30.00 \%$ occurred frequently among omnivores whereas Dorylaimus stagnalis $(\mathrm{N}=5)$ and $\mathrm{AF}=8.33 \%$ was the least frequent among omnivores (Table 2).

\section{Density}

Cephalobus parvus was the most dominant species (MD $=30.60$ ) among bacteriovores, with relative density of $6.53 \%$. The least dominant species was Wilsonema bangaloreiensis $(\mathrm{MD}=0.82)$ with relative density of $0.18 \%$. Aporcelaimellus tropicus $(\mathrm{MD}=15.10)$ dominated among predators with relative density of $3.22 \%$ while Paractinolaimus macrolaimus $(\mathrm{MD}=0.89$ ) with relative density of $0.19 \%$. Among fungivores, Aphelenchoides composticola $(\mathrm{MD}=11.76)$ dominated the group with relative density of $2.51 \%$ whereas the representation of Tyleptus projectus $(\mathrm{MD}=0.98)$ was the least with relative density of $0.21 \%$. Tylenchorhynchus mashhoodi $(\mathrm{MD}=9.46)$ was dominated among herbivores with relative density of $2.02 \%$ while Longidorus brevicaudatus $(\mathrm{MD}=0.99)$ was the least frequent with relative density of $0.21 \%$. Among omnivores Moshajia idiophora $(\mathrm{MD}=11.05)$ dominated the group with relative density of $2.36 \%$ and Dorylaimus stagnalis $(\mathrm{MD}=2.61)$ was least frequent with relative density of $0.56 \%$ (Table 2 ).

\section{Mean Biomass}

The data of the inorganic enriched habitats revealed that the biomass of predators to be the greatest) among all groups i.e., predators (46\%), followed by bacteriovores (28\%), omnivores (18\%) and herbivores $(6 \%)$ and fungivores (2\%). Acrobeles thornei constituted the highest biomass among bacteriovores, with a mean value of $43.84 \mu \mathrm{g}$ and relative mean biomass of $2.83 \%$. The least biomass was recorded for Udonchus tenuicaudatus $(0.52 \mu \mathrm{g})$ with relative mean biomass of $0.03 \%$. Among predators, the species Discolaimus similis being the large sized and, having a comparatively high density, had the highest mean biomass $(141.80 \mu \mathrm{g})$ and relative mean biomass of $7.86 \%$ and the least was recorded for Fictor $\operatorname{vorax}(10.93 \mu \mathrm{g})$ and relative mean biomass of $0.61 \%$. Among fungivore nematodes, Ditylencus dipsaci constituted the highest mean biomass $(17.20 \mu \mathrm{g})$ and had a relative mean biomass of $0.95 \%$ while Filenchus vulgaris $(1.17 \mu \mathrm{g}, \mathrm{RMB}=0.06)$ had the least mean biomass in this group. Although Hemicriconemoides magniferae was the most dominant species in the herbivore group, Longidorous brevicaudatus being large-sized, had the highest mean biomass $(70.80 \mu \mathrm{g})$ and a relative mean biomass of $3.92 \%$. Pratylenchus similis due to its small size had the least mean biomass $(1.93 \mu \mathrm{g})$ with a relative mean biomass of $0.11 \%$. The species Dorylaimus stagnalisis due to its large sized having and having a comparatively high density, had the highest mean biomass $(473.25 \mu \mathrm{g})$ and relative mean biomass of $26.23 \%$ in the omnivore group, while the species Mesodorylaimus intermedius $(24.77 \mu \mathrm{g}, \mathrm{RMB}=$ 1.37) had the least mean biomass (Table 2).

\section{Undisturbed habitats \\ Diversity and abundance}

A total of seventy-two nematode species belonging to 10 orders and 35 families were identified. A minimum of twelve and a maximum of twenty-three species per sample were recorded, with most of the samples containing twelve-twenty genera. In terms of individual abundance, the numbers of nematodes in a sample ranged from 300-900 specimens with mean a value of $696.93 \pm 248.36$ per $100 \mathrm{cc}$ of soil were recorded with most of the samples containing 400-700 individuals. In terms of taxonomic groups, order Dorylaimida was found to be the most prevalent (32\%) followed Rhabditida (25\%), Tylenchida (15\%), Plectida (7\%), Triplonchida with (6\%), Enoplida and Mononchida (4\% each), Aphelenchida, Chromodorida, with (3\% each) and the least was Monhysterida with (1\%) occurrence rate. In terms of abundance also, Order Dorylaimida was most dominant group (33\%), followed by Rhabditida (25\%), Tylenchida (20\%), Triplonchida (5\%), Enoplida, Mononchida and Plectida (4\% each), Aphelenchida (3\%) and the least were represented by Chromodorida and Monhysterida, and (1\% each) occurrence rate (Fig.1. E$\mathrm{F})$. 
Trophic groups

The trophic structure of the undisturbed habitats represented by the nematode categories of bacterivores, carnivores (predators), herbivores, omnivores and fungivores. Of the different trophic groups, the bacteriovores represented representing the highest number $(37 \%)$ followed by predators $(24 \%)$, herbivores
(18\%) fungivores (11\%), and omnivores shows the $(10 \%)$ occurrence rate. In terms of individual abundance too, bacteriovores constituted the most dominant group $(41 \%)$ followed by predators $(23 \%)$, herbivores $(16 \%)$. Representation of fungivores $(11 \%)$ and omnivores were the least with (9\%) occurrence rate (Fig.2. E-F).

Table 2. Population structure of soil inhabiting nematodes genera/species in Inorganic enriched environment.

\begin{tabular}{|c|c|c|c|c|c|c|}
\hline Genera/species & $\mathbf{N}$ & $\mathbf{A F} \%$ & MD & RD\% & MB & RMB \% \\
\hline \multicolumn{7}{|l|}{ BACTERIOVORES } \\
\hline Achromadora ruricola & 15.00 & 25.00 & 6.56 & 1.40 & 11.02 & 0.61 \\
\hline Acrobeles thornei & 34.00 & 56.67 & 28.23 & 6.03 & 43.84 & 2.43 \\
\hline Acrobeloides nanus & 32.00 & 53.33 & 26.30 & 5.61 & 12.82 & 0.71 \\
\hline Alaimus assamensis & 6.00 & 10.00 & 2.14 & 0.46 & 7.70 & 0.43 \\
\hline Brevibucca punctata & 7.00 & 11.67 & 2.84 & 0.61 & 18.01 & 1.00 \\
\hline Ceratoplectus armatus & 4.00 & 6.67 & 1.04 & 0.22 & 2.81 & 0.16 \\
\hline Cephalobus parvus & 40.00 & 66.67 & 30.60 & 6.53 & 16.07 & 0.89 \\
\hline Cervidellus vexilliger & 15.00 & 25.00 & 6.66 & 1.42 & 4.26 & 0.24 \\
\hline Chiloplacus subtenuis & 33.00 & 55.00 & 27.01 & 5.76 & 36.34 & 2.01 \\
\hline Chronogaster neotypica & 18.00 & 30.00 & 10.61 & 2.26 & 13.09 & 0.73 \\
\hline Diploscapter indicus & 16.00 & 26.67 & 7.41 & 1.58 & 1.67 & 0.09 \\
\hline Drilocephalobus alykhani & 4.00 & 6.67 & 0.98 & 0.21 & 1.47 & 0.08 \\
\hline Eucephalobus striatus & 30.00 & 50.00 & 19.64 & 4.19 & 11.00 & 0.61 \\
\hline Geomonhystera glandulata & 8.00 & 13.33 & 3.42 & 0.73 & 7.95 & 0.44 \\
\hline Heterocephalobellus magnificus & 10.00 & 16.67 & 7.86 & 1.68 & 10.85 & 0.60 \\
\hline Mesorhabditis cranganorensis & 36.00 & 60.00 & 29.32 & 6.26 & 5.86 & 0.32 \\
\hline Monhystera paludicola & 12.00 & 20.00 & 5.89 & 1.26 & 11.49 & 0.64 \\
\hline Monhystrella gracilis & 15.00 & 25.00 & 6.64 & 1.42 & 2.92 & 0.16 \\
\hline Nothacrobeles maximus & 7.00 & 11.67 & 2.42 & 0.52 & 14.52 & 0.80 \\
\hline Oscheius tipulae & 20.00 & 33.33 & 9.56 & 2.04 & 16.06 & 0.89 \\
\hline Panagrolaimus hygrophilus & 16.00 & 26.67 & 8.18 & 1.75 & 6.14 & 0.34 \\
\hline Panagrellus redivivus & 15.00 & 25.00 & 5.22 & 1.11 & 10.86 & 0.60 \\
\hline Plectus parvus & 27.00 & 45.00 & 14.17 & 3.02 & 4.72 & 0.26 \\
\hline Plectus parietinus & 24.00 & 40.00 & 8.56 & 1.83 & 1.71 & 0.09 \\
\hline Prismatolaimus intermedius & 20.00 & 33.33 & 7.23 & 1.54 & 3.90 & 0.22 \\
\hline Rhabdolaimus terrestris & 17.00 & 28.33 & 3.26 & 0.70 & 1.04 & 0.06 \\
\hline Stegellata jaisalmerensis & 7.00 & 11.67 & 1.11 & 0.24 & 1.62 & 0.09 \\
\hline Teratorhabditis synpapillata & 16.00 & 26.67 & 6.66 & 1.42 & 36.96 & 2.05 \\
\hline Udonchus tenuicaudatus & 9.00 & 15.00 & 1.11 & 0.24 & 0.52 & 0.03 \\
\hline Wilsonema bangaloreiensis & 5.00 & 8.33 & 0.82 & 0.18 & 0.79 & 0.04 \\
\hline Zeldia punctata & 6.00 & 10.00 & 1.16 & 0.25 & 8.58 & 0.48 \\
\hline Sum & 524.00 & 873.33 & 292.61 & 62.45 & 326.58 & 18.10 \\
\hline Mean & 16.90 & 28.17 & 9.44 & 2.01 & 10.53 & 0.58 \\
\hline SD & 10.42 & 17.37 & 9.38 & 2.00 & 10.83 & 0.60 \\
\hline \multicolumn{7}{|l|}{ FUNGIVORES } \\
\hline Aphelenchoides composticola & 22.00 & 36.67 & 11.76 & 2.51 & 2.57 & 0.14 \\
\hline Aphelenchus avenae & 17.00 & 28.33 & 6.45 & 1.38 & 1.82 & 0.10 \\
\hline Ditylencus dipsaci & 10.00 & 16.67 & 4.41 & 0.94 & 17.20 & 0.95 \\
\hline Filenchus vulgaris & 13.00 & 21.67 & 4.21 & 0.90 & 1.17 & 0.06 \\
\hline Leptonchus buccatus & 7.00 & 11.67 & 2.16 & 0.46 & 11.85 & 0.66 \\
\hline Tylencholaimus ibericus & 13.00 & 21.67 & 5.14 & 1.10 & 8.78 & 0.49 \\
\hline Tyleptus projectus & 6.00 & 10.00 & 0.98 & 0.21 & 4.51 & 0.25 \\
\hline Sum & 88.00 & 146.67 & 35.11 & 7.49 & 47.89 & 2.65 \\
\hline Mean & 12.57 & 20.95 & 5.02 & 1.07 & 6.84 & 0.38 \\
\hline SD & 5.62 & 9.37 & 3.49 & 0.74 & 6.02 & 0.33 \\
\hline \multicolumn{7}{|l|}{ HERBIVORES } \\
\hline Helicotylenchus dihystera & 12.00 & 20.00 & 8.86 & 1.89 & 12.85 & 0.71 \\
\hline Hemicriconemoides magniferae & 28.00 & 46.67 & 7.96 & 1.70 & 4.61 & 0.26 \\
\hline
\end{tabular}




$\begin{array}{lcccccc}\text { Hemicyclophora dhirendri } & 20.00 & 33.33 & 5.11 & 1.09 & 4.45 & 0.25 \\ \text { Hoplolaimus galeatus } & 14.00 & 23.33 & 6.13 & 1.31 & 27.59 & 1.53 \\ \text { Pratylenchus similis } & 8.00 & 13.33 & 2.14 & 0.46 & 1.93 & 0.11 \\ \text { Tylenchorhynchus mashhoodi } & 14.00 & 23.33 & 9.46 & 2.02 & 15.81 & 0.88 \\ \text { Tylenchus agricola } & 8.00 & 13.33 & 1.15 & 0.25 & 5.87 & 0.33 \\ \text { Longidorus brevicaudatus } & 5.00 & 8.33 & 0.99 & 0.21 & 70.80 & 3.92 \\ \text { Sum } & 109.00 & 181.67 & 41.80 & 8.92 & 143.89 & 7.97 \\ \text { Mean } & 13.63 & 22.71 & 5.23 & 1.12 & 17.99 & 1.00 \\ \text { SD } & 7.44 & 12.41 & 3.45 & 0.74 & 22.93 & 1.27 \\ \text { OMNIVORES } & & & & & & \\ \text { Dorylaimus stagnalis } & 5.00 & 8.33 & 2.61 & 0.56 & 473.25 & 26.23 \\ \text { Mesodorylaimus intermedius } & 15.00 & 25.00 & 6.45 & 1.38 & 24.77 & 1.37 \\ \text { Moshajia idiophora } & 18.00 & 30.00 & 11.05 & 2.36 & 38.31 & 2.12 \\ \text { Sum } & 38.00 & 63.33 & 20.11 & 4.29 & 536.32 & 29.72 \\ \text { Mean } & 12.67 & 21.11 & 6.70 & 1.43 & 599.39 & 33.22 \\ \text { SD } & 6.81 & 11.34 & 4.23 & 0.90 & 1174.02 & 65.06 \\ \text { PREDATORS } & & & & & & \\ \text { Acrostichus nudicapitatus } & 12.00 & 20.00 & 8.46 & 1.81 & 17.77 & 0.98 \\ \text { Aporcelaimellus tropicus } & 18.00 & 30.00 & 15.10 & 3.22 & 122.31 & 6.78 \\ \text { Brevitobrilus glandulatus } & 12.00 & 20.00 & 5.11 & 1.09 & 41.14 & 2.28 \\ \text { Diplogastrellus sikorai } & 7.00 & 11.67 & 4.12 & 0.88 & 17.30 & 0.96 \\ \text { Discolaimus similis } & 20.00 & 33.33 & 12.12 & 2.59 & 141.80 & 7.86 \\ \text { Fictor vorax } & 5.00 & 8.33 & 3.14 & 0.67 & 10.93 & 0.61 \\ \text { Iotonchus indicus } & 10.00 & 16.67 & 4.36 & 0.93 & 106.73 & 5.91 \\ \text { Ironus longicaudatus } & 16.00 & 26.67 & 8.89 & 1.90 & 45.01 & 2.49 \\ \text { Mononchoides fortidens } & 10.00 & 16.67 & 6.56 & 1.40 & 70.85 & 3.93 \\ \text { Mononchus aquaticus } & 6.00 & 10.00 & 1.45 & 0.31 & 18.13 & 1.00 \\ \text { Paractinolaimus macrolaimus } & 5.00 & 8.33 & 0.89 & 0.19 & 26.17 & 1.45 \\ \text { Tobrilus longus } & 20.00 & 33.33 & 8.69 & 1.85 & 131.65 & 7.30 \\ \text { Sum } & 141.00 & 235.00 & 78.89 & 16.84 & 749.78 & 41.55 \\ \text { Mean } & 11.75 & 19.58 & 6.57 & 1.40 & 62.48 & 3.46 \\ \text { SD } & 5.61 & 9.35 & 4.27 & 0.91 & 49.94 & 2.77 \\ & & & & & & \end{array}$

\section{Frequency}

Density

Among bacteriovores, the highest frequency was recorded for Acrobeles complexus $(\mathrm{N}=40)$ with an absolute frequency of $66.67 \%$. The species Macrolaimellus iucundus, Tylocephalus primitivus and Udonchus tenuicaudatus were the least frequent $(\mathrm{N}=3$ with $\mathrm{AF}=5.00 \%$ each). Among predators, the species Discolaimus major was the most prevalent $(\mathrm{N}=19)$ with absolute frequency (AF) of $31.67 \%$, whereas the least frequent species were Miconchus digiturus and Nygolaimus harislii with ( $\mathrm{N}=4$ and $\mathrm{AF}=6.67 \%$ each $)$. Aphelenchus avenae was the most frequent species among fungivores representing $(\mathrm{N}=23)$ with absolute frequency (AF) of $38.33 \%$ while Tantunema intermedium $(\mathrm{N}=7)$ was the least frequent species among fungivores with $\mathrm{AF}=11.67 \%$. Among plant parasitic or herbivores Helicotylenchus dihystera was the most prevalent with $(\mathrm{N}=20)$ and $\mathrm{AF}=33.33 \%$. The least occurring species were Psilenchus hilarulus and Trichodorus complexus with $(\mathrm{N}=4)$ and $\mathrm{AF}=6.67 \%$ each. The species Eudorylaimus carteri $(\mathrm{N}=16)$ and $\mathrm{AF}$ $=26.67 \%$ occurred frequently among omnivores whereas Thonus cylindricus $(\mathrm{N}=3)$ and $\mathrm{AF}=5.00 \%$ was the least frequent among omnivores (Table 3 ).

Acrobeles complexus was the most dominant species $(\mathrm{MD}=27.45)$ among bacteriovores, with relative density of $6.18 \%$. The least dominant species were Macrolaimellus iucundus Tylocephalus primitivus and Udonchus tenuicaudatus with $(\mathrm{MD}=0.90),(\mathrm{MD}=$ $0.92),(\mathrm{MD}=0.92)$ and relative density of $0.20 \%, 0.21 \%$ and $0.21 \%$ respectively. Discolaimus major $(\mathrm{MD}=$ 15.61) dominated predators with relative density of $3.51 \%$ while Nygolaimus harislii $(\mathrm{MD}=1.01)$, with relative density of $2.30 \%$ was least frequent among the group. Among fungivores, Aphelenchus avenae ( $\mathrm{MD}=$ 10.22) dominated the group with relative density of $2.30 \%$ whereas the representation of Tantunema intermedium ( $\mathrm{MD}=1.41$ ) was the least with relative density of $0.32 \%$. Helicotylenchus dihystera $(\mathrm{MD}=$ 9.14) dominated among herbivores, with relative density of $2.06 \%$ while Trichodorus complexus $(\mathrm{MD}=0.94$ ) was the least frequent with relative density of $0.21 \%$. Among omnivores, Moshajia idiofora $(\mathrm{MD}=9.11)$ dominated the group with relative density of $2.05 \%$ and Thonus cylindricus $(\mathrm{MD}=0.75)$ least frequent with relative density of $0.17 \%$ (Table 3 ). 


\section{Mean Biomass}

The data of the undisturbed habitats revealed that the biomass of predators to be the greatest among all groups i.e., Predators $(47 \%)$, followed by bacteriovores $(21 \%)$, omnivores $(15 \%)$ and herbivores $(13 \%)$ and fungivores (4\%). Poikilolaimus jodhpurensis constituted the highest biomass among bacteriovores, with a mean value of $(57.97 \mu \mathrm{g})$ and relative mean biomass of $2.60 \%$. The least biomass was recorded for Tylocephalus primitivus $(0.92 \mu \mathrm{g})$, with relative mean biomass of $0.04 \%$. Among predators, Discolaimus major was most frequent but the species Aporcelaimellus heynsi being the large sized had the highest mean biomass $(211.65 \mu \mathrm{g})$ and relative mean biomass of $9.49 \%$ and the least was recorded for Nygolaimus harislii $(14.85 \mu \mathrm{g})$ and relative mean biomass of $0.67 \%$. Among fungal feeding nematodes, Dorylaimellus indicus constituted the highest mean biomass $(39.66 \mu \mathrm{g})$ and had a relative mean biomass of $1.78 \%$ while Aglenchus agricola $(2.24 \mu \mathrm{g}, \mathrm{RMB}=0.10)$ had the least mean biomass in this group. Although Helicotylenchus dihystera was the most dominant species in the herbivore group, Longidorus elongates being large-sized, had the highest mean biomass (169.49 $\mu \mathrm{g}$ ) and a relative mean biomass of $7.60 \%$. Basiria abberans due to its small size had the least mean biomass $(2.95 \mu \mathrm{g})$ with a relative mean biomass of $0.13 \%$. The species Eudorylaimus carteri being large sized and having a comparatively high density, had the highest mean biomass $(131.83 \mu \mathrm{g})$ and relative mean biomass of $5.91 \%$ in the omnivore group, while the Amphidorylaimus flagellicauda $(4.95 \mu \mathrm{g}, \mathrm{RMB}=0.22)$ had the least mean biomass (Table 3 ).

Nematode community dynamics in organic enriched, inorganic enriched and undisturbed habitats

For assessing the community dynamics and indicative role of nematodes in different terrestrial habitats various indices such as Shannon's diversity index ( $\left.\mathrm{H}^{\prime}\right)$, Maturity index (MI) including plant parasitic families (PPI), Maturity index 2-5, Plant parasitic index (PPI), Trophic Diversity Index (TDI), Channel Index (CI), Nematode channel ratio (NCR), Enrichment Index (EI), Structure Index (SI) and Basal Index (BI) were calculated (Table 5; Fig.3).

Table 3. Population structure of soil inhabiting nematodes genera/species in Undisturbed environment.

\begin{tabular}{|c|c|c|c|c|c|c|}
\hline \multirow{2}{*}{\multicolumn{7}{|c|}{$\begin{array}{l}\text { Genera/species } \\
\text { BACTERIOVORES }\end{array}$}} \\
\hline & & & & & & \\
\hline Achromadora indica & 10.00 & 16.67 & 3.56 & 0.80 & 8.12 & 0.36 \\
\hline Acrobeles complexus & 40.00 & 66.67 & 27.45 & $6.18 \circlearrowleft$ & 6.59 & 0.30 \\
\hline Acrobeles cylindricus & 25.00 & 41.67 & 15.60 & 3.51 & 4.49 & 0.20 \\
\hline Acrobeloides nanus & 34.00 & 56.67 & 19.99 & 4.50 & 9.17 & 0.41 \\
\hline Acrobelophis minimus & 15.00 & 25.00 & 5.69 & $1.28=$ & 1.82 & 0.08 \\
\hline Alaimus primitivus & 16.00 & 26.67 & 6.12 & 1.38 & 6.20 & 0.28 \\
\hline Amphidelus sylvaticus & 11.00 & 18.33 & 3.78 & 0.85 & 7.22 & 0.32 \\
\hline Cephalobus persegnis & 26.00 & 43.33 & 15.21 & 3.42 & 8.42 & 0.38 \\
\hline Cervidellus vex & 18.00 & 30.00 & 6.21 & 1.40 & 8.49 & 0.38 \\
\hline Chiloplacus symmetricus & 38.00 & 63.33 & 24.31 & 5.47 & 43.37 & 1.94 \\
\hline Chronogaster typica & 12.00 & 20.00 & 3.54 & 0.80 & 6.90 & 0.31 \\
\hline Diploscapter coronatus & 6.00 & 10.00 & 4.13 & 0.93 & 3.72 & 0.17 \\
\hline Eucephalobus striatus & 20.00 & 33.33 & 14.34 & 3.23 & 12.05 & 0.54 \\
\hline Macrolaimellus iucundus & 3.00 & 5.00 & 0.90 & 0.20 & 2.16 & 0.10 \\
\hline Mesorhabditis vernalis & 28.00 & 46.67 & 21.36 & 4.81 & 11.44 & 0.51 \\
\hline Metarhabditis amsactae & 12.00 & 20.00 & 5.98 & 1.35 & 21.53 & 0.97 \\
\hline Monhystera rolandi & 8.00 & 13.33 & 3.69 & 0.83 & 11.35 & 0.51 \\
\hline Oscheius zarinae & 15.00 & 25.00 & 8.96 & 2.02 & 23.65 & 1.06 \\
\hline Panagrolaimus filiformis & 20.00 & 33.33 & 13.36 & 3.01 & 8.42 & 0.38 \\
\hline Pelodera aligarhensis & 7.00 & 11.67 & 2.42 & 0.54 & 23.02 & 1.03 \\
\hline Plectus parvus & 16.00 & 26.67 & 8.96 & 2.02 & 2.69 & 0.12 \\
\hline Poikilolaimus jodhpurensis & 10.00 & 16.67 & 3.21 & 0.72 & 57.97 & 2.60 \\
\hline Prismatolaimus intermedius & 14.00 & 23.33 & 4.30 & 0.97 & 3.32 & 0.15 \\
\hline Rhabdolaimus terrestris & 4.00 & 6.67 & 0.84 & 0.19 & 1.13 & 0.05 \\
\hline Tylocephalus primitivus & 3.00 & 5.00 & 0.92 & 0.21 & 0.92 & 0.04 \\
\hline Udonchus tenuicaudatus & 3.00 & 5.00 & 0.92 & 0.21 & 1.29 & 0.06 \\
\hline Zeldia punctata & 7.00 & 11.67 & 2.21 & 0.50 & 14.02 & 0.63 \\
\hline Sum & 421.00 & 701.67 & 227.96 & 51.30 & 309.46 & 13.88 \\
\hline Mean & 15.59 & 25.99 & 8.44 & 1.90 & 11.46 & 0.51 \\
\hline SD & 9.21 & 15.34 & 6.83 & 1.54 & 14.49 & 0.65 \\
\hline \multicolumn{7}{|l|}{ FUNGIVORES } \\
\hline Aglenchus agricola & 11.00 & 18.33 & 4.56 & 1.03 & 2.24 & 0.10 \\
\hline Aphelenchoides composticola & 17.00 & 28.33 & 8.69 & 1.96 & 2.45 & 0.11 \\
\hline
\end{tabular}




\begin{tabular}{|c|c|c|c|c|c|c|}
\hline Aphelenchus avenae & 23.00 & 38.33 & 10.22 & 2.30 & 2.40 & 0.11 \\
\hline Dorylaimoides bulbosus & 14.00 & 23.33 & 5.96 & 1.34 & 25.80 & 1.16 \\
\hline Dorylaimellus indicus & 12.00 & 20.00 & 6.61 & 1.49 & 39.66 & 1.78 \\
\hline Leptonchus granulosus & 9.00 & 15.00 & 1.98 & 0.45 & 6.07 & 0.27 \\
\hline Tantunema intermedium & 7.00 & 11.67 & 1.41 & 0.32 & 4.11 & 0.18 \\
\hline Tylencholaimellus projectus & 15.00 & 25.00 & 6.54 & 1.47 & 11.51 & 0.52 \\
\hline Sum & 108.00 & 180.00 & 45.97 & 10.35 & 94.24 & 4.23 \\
\hline Mean & 13.50 & 22.50 & 5.75 & 1.29 & 11.78 & 0.53 \\
\hline SD & 5.01 & 8.36 & 3.04 & 0.68 & 13.79 & 0.62 \\
\hline \multicolumn{7}{|l|}{ HERBIVORES } \\
\hline Basiria abberans & 6.00 & 10.00 & 2.11 & 0.47 & 2.95 & 0.13 \\
\hline Criconemoides informis & 9.00 & 15.00 & 3.15 & 0.71 & 15.96 & 0.72 \\
\hline Hemicriconemoides magniferae & 10.00 & 16.67 & 7.92 & 1.78 & 13.31 & 0.60 \\
\hline Helicotylenchus dihystera & 20.00 & 33.33 & 9.14 & 2.06 & 7.95 & 0.36 \\
\hline Hoplolaimus indicus & 14.00 & 23.33 & 6.66 & 1.50 & 28.83 & 1.29 \\
\hline Longidorus elongatus & 9.00 & 15.00 & 3.96 & 0.89 & 169.49 & 7.60 \\
\hline Merlinius brevidens & 7.00 & 11.67 & 2.54 & 0.57 & 3.70 & 0.17 \\
\hline Pratylenchus penetrans & 5.00 & 8.33 & 1.89 & 0.43 & 7.26 & 0.33 \\
\hline Psilenchus hilarulus & 4.00 & 6.67 & 1.01 & 0.23 & 8.48 & 0.38 \\
\hline Trichodorus complexus & 4.00 & 6.67 & 0.94 & 0.21 & 7.47 & 0.34 \\
\hline Tylenchorhynchus striatus & 17.00 & 28.33 & 5.45 & 1.23 & 4.23 & 0.19 \\
\hline Tylenchus arcuatus & 11.00 & 18.33 & 4.21 & 0.95 & 8.96 & 0.40 \\
\hline Xiphinema brevicollum & 15.00 & 25.00 & 5.11 & 1.15 & 53.35 & 2.39 \\
\hline Sum & 131.00 & 218.33 & 54.09 & 12.17 & 331.94 & 14.88 \\
\hline Mean & 10.08 & 16.79 & 4.16 & 0.94 & 25.53 & 1.14 \\
\hline SD & 5.12 & 8.54 & 2.60 & 0.58 & 45.39 & 2.04 \\
\hline \multicolumn{7}{|l|}{ OMNIVORES } \\
\hline Amphidorylaimus flagellicauda & 7.00 & 11.67 & 1.99 & $0.45 \circlearrowleft \rho$ & 4.95 & 0.22 \\
\hline Eudorylaimus carteri & 16.00 & 26.67 & 7.56 & 1.70 & 131.83 & 5.91 \\
\hline Mesodorylaimus bastiani & 11.00 & 18.33 & 3.21 & 0.72 & 19.26 & 0.86 \\
\hline Moshajia idiofora & 13.00 & 21.67 & 9.11 & $2.05 \exists$ & 83.25 & 3.73 \\
\hline Opisthodorylaimus maqsoodi & 6.00 & 10.00 & 1.42 & 0.32 & 23.29 & 1.04 \\
\hline Oriverutus hastus & 9.00 & 15.00 & 3.45 & 0.78 & 16.10 & 0.72 \\
\hline Thonus cylindricus & 3.00 & 5.00 & 0.75 & 0.17 & 44.40 & 1.99 \\
\hline Sum & 65.00 & 108.33 & 27.49 & 6.19 & 323.07 & 14.49 \\
\hline Mean & 9.29 & 15.48 & 3.93 & 0.88 & 46.15 & 2.07 \\
\hline SD & 4.42 & 7.37 & 3.19 & 0.72 & 45.77 & 2.05 \\
\hline \multicolumn{7}{|l|}{ PREDATORS } \\
\hline Actinolaimus armatus & 6.00 & 10.00 & 2.98 & 0.67 & 45.89 & 2.06 \\
\hline Aporcelaimellus heynsi & 15.00 & 25.00 & 14.11 & 3.18 & 211.65 & 9.49 \\
\hline Aquatides intermedius & 5.00 & 8.33 & 1.89 & 0.43 & 61.92 & 2.78 \\
\hline Butlerius butleri & 5.00 & 8.33 & 2.98 & 0.67 & 27.54 & 1.23 \\
\hline Discolaimium dubium & 6.00 & 10.00 & 3.02 & 0.68 & 22.65 & 1.02 \\
\hline Discolaimus major & 19.00 & 31.67 & 15.61 & 3.51 & 155.28 & 6.96 \\
\hline Ironus dentifurcatus & 13.00 & 21.67 & 8.44 & 1.90 & 45.97 & 2.06 \\
\hline Laimydorus siddiqii & 7.00 & 11.67 & 3.14 & 0.71 & 107.93 & 4.84 \\
\hline Labronema neodiversum & 9.00 & 15.00 & 4.96 & 1.12 & 69.77 & 3.13 \\
\hline Lordellonmena indicum & 8.00 & 13.33 & 4.11 & 0.92 & 26.20 & 1.17 \\
\hline Makatinus heynsi & 11.00 & 18.33 & 4.22 & 0.95 & 84.02 & 3.77 \\
\hline Miconchus digiturus & 4.00 & 6.67 & 1.11 & 0.25 & 33.97 & 1.52 \\
\hline Mononchus truncatus & 7.00 & 11.67 & 2.98 & 0.67 & 48.28 & 2.16 \\
\hline Mylonchulus brachyuris & 10.00 & 16.67 & 7.97 & 1.79 & 69.34 & 3.11 \\
\hline Nygolaimus harislii & 4.00 & 6.67 & 1.01 & 0.23 & 14.85 & 0.67 \\
\hline Oigolaimella longicauda & 5.00 & 8.33 & 2.45 & 0.55 & 29.11 & 1.31 \\
\hline Tobrilus gracilis & 7.00 & 11.67 & 6.01 & 1.35 & 100.97 & 4.53 \\
\hline Trischistoma pellucidum & 5.00 & 8.33 & 1.86 & 0.42 & 16.29 & 0.73 \\
\hline Sum & 146.00 & 243.33 & 88.85 & 20.00 & 1171.60 & 52.53 \\
\hline Mean & 8.11 & 13.52 & 4.94 & 1.11 & 65.09 & 2.92 \\
\hline SD & 4.11 & 6.86 & 4.17 & 0.94 & 52.05 & 2.33 \\
\hline
\end{tabular}




\section{Weighted faunal analysis}

Food web diagnostics of three different habitats were compared in terms of Enrichment index (EI), Structure index (SI) and Basal index (BI) following the weighed faunal analysis concept of Ferris et al. (2001). Organic enriched habitats revealed that most of the values for SI and EI lies in quadrat ' $A$ ' and some of the in quadrat ' $D$ ' indicating highly enriched, disturbed and unstructured ecosystem with some moderate to low basal conditions. Inorganic enriched habitats data revealed that most of the values for SI and EI lies in quadrat ' $D$ ' and ' $A$ ' while some values cluster in quadrat ' $\mathrm{C}$ ' reflecting highly basal and moderate to highly enriched ecosystem. conditions. Undisturbed habitats showed most of the sampling sites indicating high enrichment while few indicated high structured status of the ecosystem (Fig. 4).

\section{Correlations among different variables}

The biplot graph (Fig. 5) depicts the correlation of different variables differencing the three different terrestrial habitats.
We did multivariate analysis viz., Principal component analysis (PCA) program to know the relationship between the variables and retrieved a correlation circle (Fig.6), which depicts the correlations among various variables. Structure index showed a positive correlation with fungivores, herbivores, omnivores and predators while negative correlation with bacterivores. Almost all the trophic groups except bacterivores showed a positive relationship with SI, Plant Parasitic Index/PPI, TDI and MI. SI also depicted low positive relationship with CI while negative correlation with NCR. Bacterivores showed positive correlation with EI and BI while rest of trophic group showed a negative correlation with EI and BI. Only bacterivores indicated robust positive correlation with EI in comparison to other trophic groups. EI almost showed no correlation with PPI. The explanation for these correlations would be understood after analyzing the biplot graph.

Figure 3. Ecological Indices
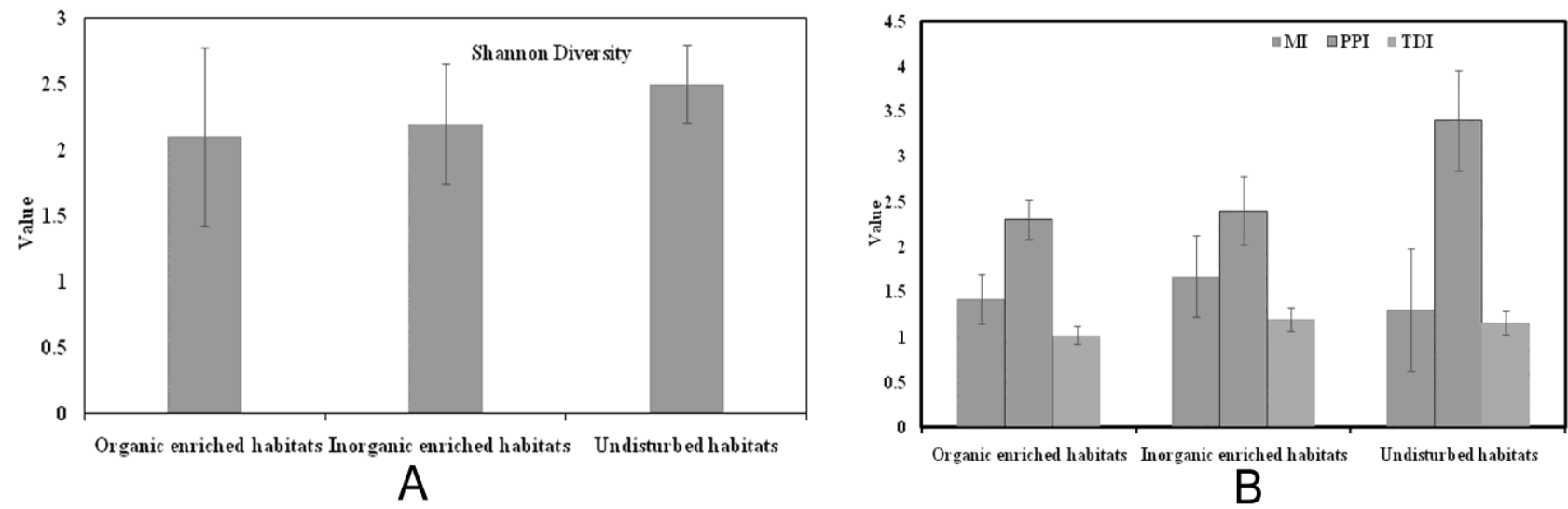

B
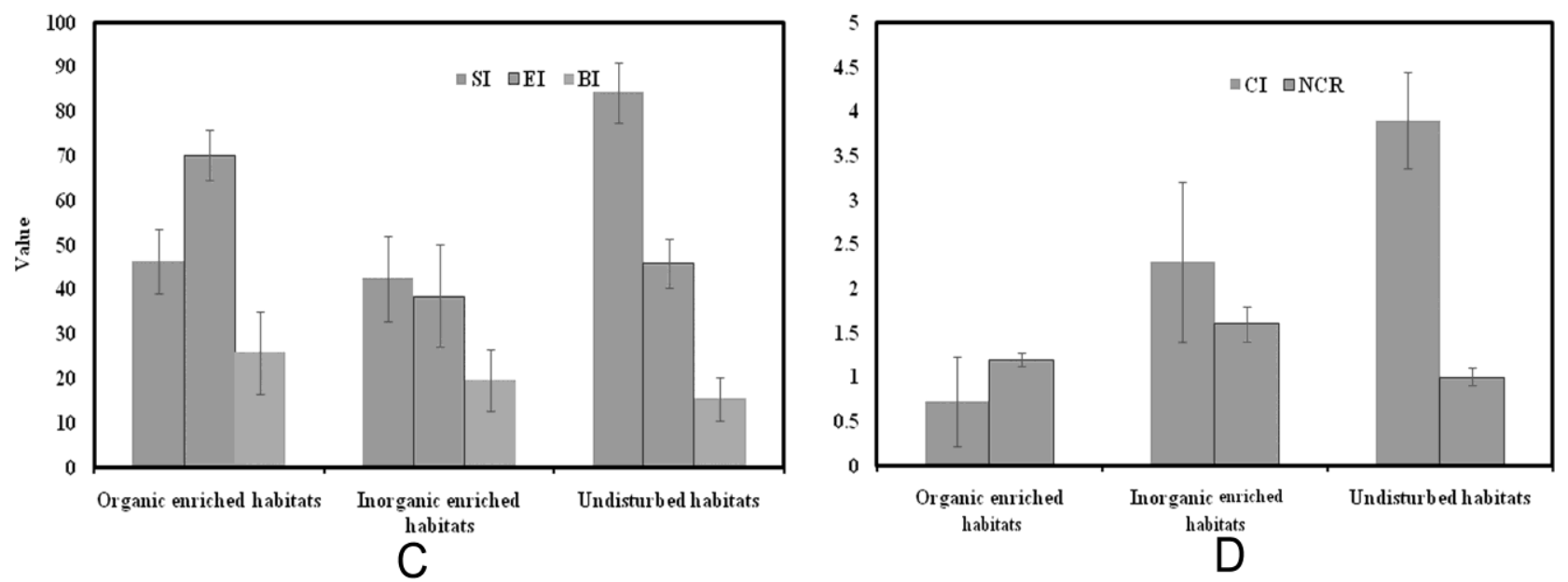

*Relationship and comparison of different diversity and ecological indices in three different habitats: A: Shannon diversity; B: Maturity Index (MI), Plant Parasitic Index (PPI) and Trophic Diversity Index; C: Structure Index (SI), Enrichment Index (EI) and Basal Index (BI); D: Channel Index (CI) and Nematode Channel Ratio (NCR). 
Figure 4. Quadrate

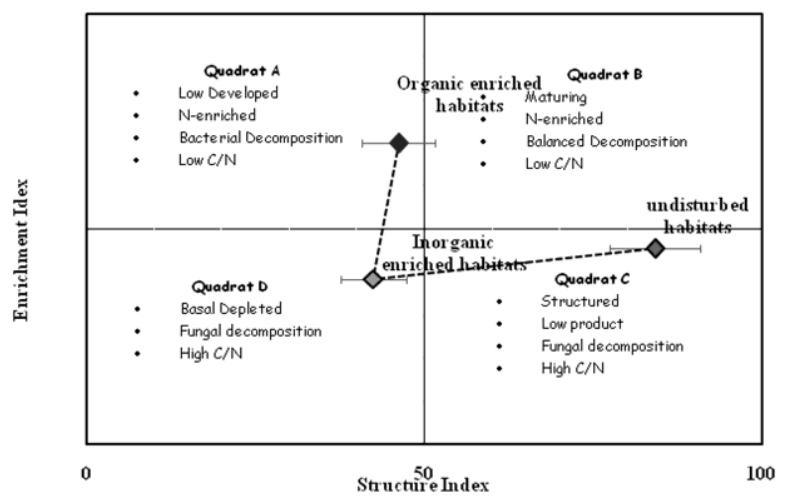

*Quadrat analysis [Graph constructed using functional guild approach, after Ferris (2001)] depicting comparative status and stability of three different habitats.

Figure 5. Biplot

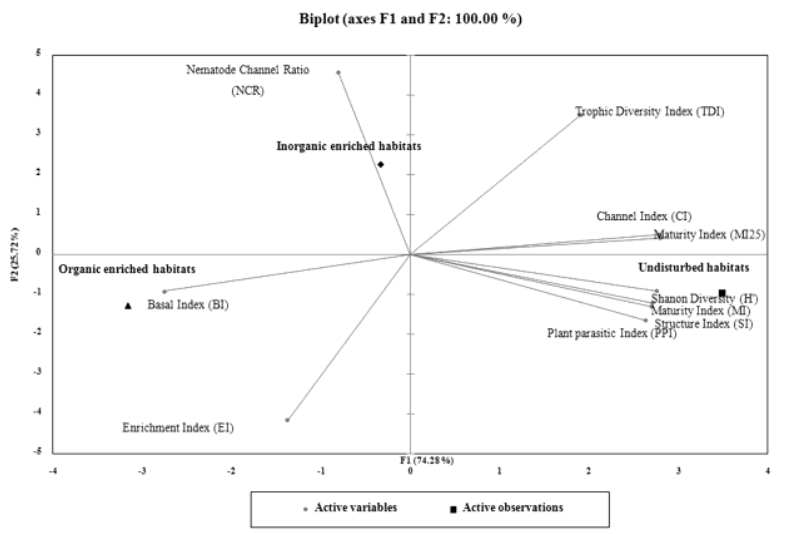

*Biplot ordination (PCA) of observation on trophic group abundance in terms of species, total nematode abundance and various other variables in three different fields.

Figure 6. Correlation circle

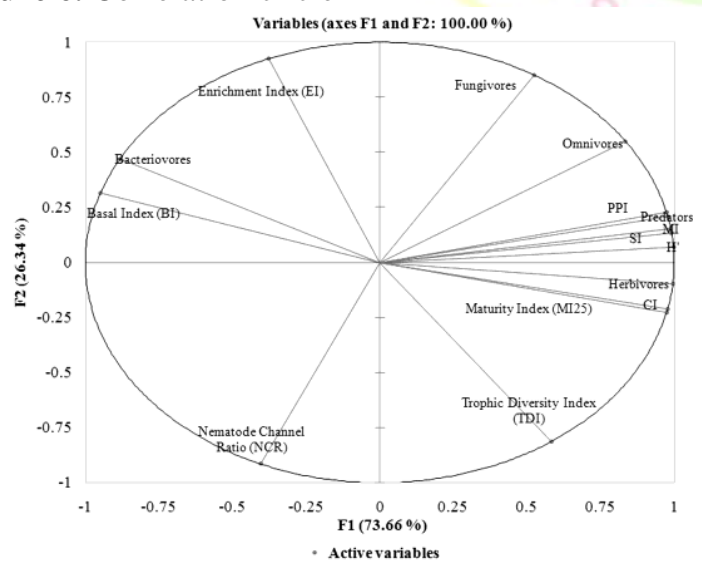

*Biplot correlation circle depicting the correlation between the different variables.

In Biplot ordination, graph the the active variables and active observations clearly give the idea how would the different ecological indices viz., Maturity Index (MI),
Plant parasitic Index (PPI), Channel Index (CI), Basal Index (BI), Maturity Index (MI) Trophic Diversity Index (TDI), Structure Index (SI), Enrichment Index (EI) and Nematode Channel Ratio (NCR) clearly demarcating the three different soil ecological system. The different habitats can be clearly differentiated with respect to different parameters used in the analysis. The angle between the active variables (Ecological indices) and active observation (habitats) may be acute, right or obtuse to the suggesting positive, nil and negative correlation respectively. In the present study, all the three different habitats (Active Observation) can be clearly differentiated with respect to active variables (ecological indices and generic diversity). In natural terrestrial undisturbed habitat, we get the cluster of MI, SI, PPI and $\mathrm{H}^{\prime}$ suggesting these variables are positively correlated and also the habitat is negatively correlated with NCR, BI and EI suggest the negative correlation and would have low values of these indices with respect to all other habitats considered for analysis. In other two active observation (Inorganic Enriched habitat) BI and NCR is Positively correlation suggesting very basal condition and bacterivore decomposition channels operates in Inorganic Enriched habitat) In Organic enriched habitat EI is positively correlated suggesting the highly enriched condition and high number of bacterivores.

\section{Discussion}

Soil nematode assemblage and their trophic changes have been found to be one of the best biological tools for assessing soil processes and plant conditions in terrestrial ecosystems (Wang et al., 2009; Pen-Mouratov et al., 2010). Soil nematode communities represent the most abundant multicellular animal group on earth and are important component of the soil biota (Sohlenius,1980; Bongers and Bongers, 1998). Their communities have the potential to provide unique insights into many aspects of soil processes. Soil nematodes regulate the bacterial and fungal populations and thus are associated with cycling of major nutrients in soils (Ingham et al., 1985). Hence there are significant possibilities for the use of nematode populations and diversity as indicators of overall soil condition. Nematode communities are sensitive to chemical and physical disturbances in ecosystem. These disturbances can alter nematode communities in different ways (Fiscus and Neher, 2002). In natural and plantation forest ecosystems, soil nematode communities play important an important role in the functioning of ecosystem (Yeates 2003; Bakonyi et al., 2007). In forest ecosystem nematode communities appeared to be more in diverse as they are subjected to changes in food resource availability and environmental conditions Yeates (2007). The nematode diversity of specific type of habitats revealed many characteristics that proves to be useful for use as biological indicators of agricultural practices, soil characteristics, soil types (Sithole et al., 2016) and the degree of conservation of soils (Hu et al., 2011, 2014; Li et al., 2012; Zhang et al., 2012; Hu and Qi 2013; Park et al., 2013; Ugarte et al., 2013). 
The present study revealed a great degree of diversity of soil inhabiting nematodes from three different habitats across Western Uttar Pradesh. The generic diversity and abundance of the trophic groups showed substantial variations at three different habitats. The increase in the diversity and abundance of the herbivores in inorganic enriched and undisturbed pristine habitat appeared to be the only significant change. Among the taxonomic groups recorded, the order Rhabditida was the most dominant in terms of individual abundance as well as in generic diversity in all habitats this is in all probability because of the nematodes of order Rhabditida appeared to be adaptable to different types of habitats and thus represented the resulted in such morphological great morphological diversity Jahan and Tahseen (2018). Hence, they can be regarded as highly evolved clades with a great degree of adaptive radiations. These rselective opportunists indicate towards disturbance and utilize the abundant resources as colonizers to build up their populations.

Fifteen species viz., Acrobeloides nanus, Acrobeles complexus, Cephalobus parvus, Chiloplacus subtenuis, Panagrolaimus filiformis, Mesorhabditis vernalis, Aphelenchus avenae, Aphelenchoides composticola, Helicotylenchus dihystera, Hemicriconemoides magniferae, Mesodorylaimus subtiloides, Eudorylaimus carteri, Aporcelaimellus tropicus, Discolaimus similis, Discolaimus major were frequently found to be most important of the total species identified and constitute about $30.25-51.18 \%$ of total nematode community. The high frequency and dominance of these species also indicated their greater competence in variable environment and habitat types and also their cosmopolitan nature. Similar findings were reported by different workers like Eder and Kirchengast, 1982 during the study reported six species out of twenty-two species which made about made up $91 \%$ of the total nematode populations. While reported seven of seventy-one nematode species to constitute $71 \%$ of total nematode population were studied by Beier and Traunspurger (2003b).

In organic enriched habitats the presence of rhabditids particularly the Rhabditidae, Cephalobidae and Panagrolaimidae is indicative of high enrichment. The presence of Acrobeloides nanus, Chiloplacus subtenuis are well adapted to depleted conditions of resources and can withstand stress particularly the moisture stress. While the frequently abundance of species viz., Mesorhabditis vernalis, Teratorhabditis synpapillata, Diploscapter coronatus, Butlerius butleri, Oigolaimella longicauda Panagrolaimus filiformis, in organic enriched field reflected the conditions of low oxygen concentrations. Some other bacterivores viz., Tylocephalus palmatus, Oscheius shamimi. found in varios samples showed phoretic association with insects that depend on the plants in one way or other.

The inorganic habitat has somewhat stressed condition and the only tolerant nematode group was observed in high numbers viz., Cephalobus parvus, Acrobeles thornei, Chiloplacus subtenuis and Acrobeloides nanus. These findings well confirm with earlier work of Yeates and Bird (1994) and Gomes et al. (2003) where it was observed that the cephalobids were the most abundant bacterial feeders present in cropping systems. Cropping fields are mainly characterized by repeated or regular disturbances viz., cultivation, use of organic matter, pesticides and fertilizers and as a result of these types of protuberances decreases of diversity (Yeates and Bongers, 1999) and increases the number and dominance of opportunistic taxa.

The population of dorylaims was highest in undisturbed habitat, followed by rhabditids and least was observed for Monhysterids. The population was highest in undisturbed area due to the abundance of prey and predatory dorylaims. The species that were prevailing in undisturbed ecosystem were Discolaimus major, Aporcelaimellus heynsi, Ironus dentifurcatus and Makatinus heynsi. The presence of Discolaimus major might be due to it is commonly found or easily availability of food resources, moisture and may be due climatic conditions. A high diversity of dorylaim nematodes reflect less intrusion of various human activities in the field while a low number indicates more protuberances (Neher, 2001; Gomes et al., 2003).

A relatively low proportion of bacterivores can thus indicate undisturbed conditions of the soils studied. In the present study, bacterivores were the most dominant in terms of generic diversity as well as individual abundance among the trophic group recorded from organic enriched habitats and was low in undisturbed habitat.

In undisturbed forest ecosystem population of bacterivore nematodes frequently found most dominated among all trophic groups (Wasilewska, 1979; Háněl, 1997; Yeates et al., 2000) and as any protuberance in the ecosystem occur their abundance increases in soil nematode community (Sohlenius, 2002; Háněl, 2004). At undisturbed habitat, where the vegetation was substantial, in terms of abundance, the diversity of Tylenchida was highest (16\%) comparable to other habitats, i.e., inorganic enriched $(13 \%)$ and organic enriched habitats $(8 \%)$ in old organic habitat like heap of manure with time leads to the development of vegetation but the soil structure could not be observed in that habitat. In terms of genera, undisturbed habitat has highest percentage of tylenchids (18\%) followed by organic habitat (13\%) and inorganic rich habitat (9\%). In Inorganic habitat although disturbed, the tylenchids were in substantial numbers this may be due to the inorganic nutrient enrichment and development of heterogenous vegetation. And in field that were treated with inorganic fertilizers the overall generic diversity was low. The increase in the trophic diversity of the herbivores was apparently at the expense of predators and omnivores. In both the enriched habitat the diversity of fungivores is significantly less than the bacteriovores but their relative abundance was comparable perhaps representing that 
their resource utilization was better or their food source was more varied and plentiful.

Shanon's diversity index $\left(\mathrm{H}^{\prime}\right)$ reflects diversity of nematodes in an ecosystem. Higher values of $\mathrm{H}^{\prime}$ show highly diverse ecosystem while low values show the contrary. Different authors reported variation of $\mathrm{H}^{\prime}$ value in different habitats including forest area. Háněl (1995) recorded successional variation of $\mathrm{H}^{\prime}$ value and found that the number of species was lower in the initial successional stages (field, fallow) than in older ones (meadow, forest) and the greatest species and generic diversity $\left(\mathrm{H}^{\prime}\right)$ was found in meadow. Pattison et al. (2004) recorded $\mathrm{H}^{\prime}$ value of nematode diversity for banana crop (1.35), pasture (1.97) and forest (2.07). Tahseen et al. (2011) also observed higher diversity in forest region. The values of $\mathrm{H}^{\prime}$ were higher in undisturbed habitat, followed by inorganic rich habitat and the least was observed for organic rich habitats. It can be stated that organic enriched habitat is highly disturbed with high microbial activity and the conditions of high enrichment which showed less structured status of the soil and results in disturbances in soil ecosystem. The Maturity index was highest in the undisturbed area, indicating a more stable nematode community in this habitat than in others. In organic enriched habitat, the species Acrobeloides nanus was most abundant with a low c-p value, showing higher population densities as well as dominance in all the three habitats due to high organic accumulation (litter). The substantial litter accumulation in natural forests helps create a humus layer and better structured soil populations. Háněl (1996) and Čerevková and Renčo (2009) also reported that Acrobeloides was the predominating genus in undisturbed natural forests. Háněl (2001) also referred to an increasing abundance of Acrobeloides due to litter accumulation. The maturity index (MI) was calculated to assess the maturity of the forest ecosystems. MI values for soil subjected to varying levels of disturbance range from $>2.0$ in nutrient enriched disturbed systems to 4.0 in undisturbed, pristine environment (Bongers and Ferris, 1999).

Food web indices like EI, SI, BI and CI may provide an excellent means for studying the stability of ecosystem, weather it is enriched, structured or stressed and provide information on the dynamics of the soil food web (Ferris et al., 2001). EI is basically known to reflect availability of resources to the soil food web and response of primary decomposers to the resources (Ferris et al., 2004).

In organic enriched habitat the values of EI were highest $70.1 \pm 22.7(30.0-95.7)$ followed by undisturbed natural forest 52.9 $\pm 32.6(17.0-75.4)$ and was lowest in inorganic enriched habitat $48.50 \pm 32.7$ (18.0-70.4). The highest value of EI reflects its enrichment. SI represents an aggregation of functional guilds with c-p values ranging from 3-5. SI is primarily determined by omnivores and predatory nematode populations, which are highly sensitive to disturbances and need much more time to establish than opportunistic fungivore and bacteriovore nematodes (Ferris et al., 2001). SI describes whether soil ecosystem is structured (high SI) or disturbed (low SI). It has been reported in earlier studies that generally in fallow soils and forests, the value of SI is higher which may be due to high abundance of omnivores and predators suggesting a food web with more trophic linkages (Ferris and Matute, 2003). Higher the values of SI, more complex are the community structure. Fallow lands and forests have been reported to be more complex communities with reference to nematode in many studies (Tomar and Ahmad, 2009). The values of SI during present study were highest in undisturbed forest 84.2 \pm 8.4 (60.9-98.7) followed by inorganic enriched $54.5 \pm 29.3(17.0-72.9)$ and organic enriched habitats 46.2-8.9 (15.4-59.2). Ferris et al., 2001; Berkelmans et al., 2003 commented that high values of SI indicated undisturbed conditions of the ecosystems studied. The high values of MI, SI as well as diversity indicated structured nematode assemblages. This implies that a stable food web in soil can be maintained by different species composition of nematodes (Háněl and Čerevková, 2006).

The degree of fungal participation in the primary decomposition channels of soil food webs is suggested by CI. The higher values of CI indicate a fungal dominated decomposition pathway while lower value indicates the bacteria-based decomposition pathway. The values for CI in present study were higher at undisturbed forest 3.9 $\pm 0.1(3.6-4.5)$ which indicated that greater participation of fungivores in the breakdown of soil organic matter. It is an agreement with Ruess (2003) who stated that high value of CI indicated a fungal based energy channel in coniferous forest sites.

The basal index (BI) is an indicator of a food web diminished by stress or limited nutrient resources (Ferris et al., 2001). The values for BI in present study were higher at inorganic patches 19.6 \pm 8.5 (13.7-38.3) followed by organic habitat $25.7 \pm 22.9(18.8-37.8)$ and undisturbed habitat 15.3 $\pm 5.6 \quad(12.7-31.3)$ which indicated that the food web structure was probably fungal dominated in undisturbed forest our result concurred with Berkelmans et al. (2003) who stated that high value of BI indicates poor ecosystem health.

Low values of MI and SI and high values of EI, BI and $\mathrm{CI}$ in the organic enriched habitat as compared inorganic rich habitat and undisturbed habitat indicated that the soil food web was severely disrupted in that region.

The PPI is very good indicator of plant parasitic nematode resources. It is comparable to MI but computed only for plant parasitic nematodes with a rational that their abundance is determined with the vigour of the host plant, which in turn is determined by system enrichment (Bongers et al., 1997). Larger PPI values indicate low levels of disturbance to the community and are associated with dominance by slow reproducing, disturbance-intolerant 'persister' nematodes (analogous to $\mathrm{K}$ strategists). Conversely, smaller PPI values indicate high levels of disturbance and are associated with rapidly reproducing, disturbance tolerant 'colonizer' nematodes (analogous to $r$ 
strategists) (Bongers, 1990, 1999). The PPI is very good indicator of plant parasitic nematode resources. The PPI values varies in different fields viz., for good crop fields range from 2.3 (Pate et al., 2000) to 2.82 (Neher and Campbell, 1994). In waste lands uninterrupted field, the highest PPI values (2.50-3.50) indicated the presence of ample vegetation in these lands which showed undisturbed vegetation in a succession phase. The lowest PPI values for organic enriched field are probably because of limited plant resource and a lack of its variety. The relatively lower PPI of the inorganic enriched fields might be due to fact that some of the samples were collected from fallow soils which were stressed or those supplemented with manure and were disturbed due to various agricultural practices (Ou et al., 2005). The highest value in undisturbed habitats indicated that no human intervention and there is more ample vegetation or grasses which are grown when field left fallow or undisturbed.

As per observations of quadrat analysis, it can be said that organic enriched habitats found to highly enriched, disturbed and unstable conditions of the ecosystem. It reflects anthropogenic activities or disturbances in the environment. Inorganic enriched habitats revealed that stress or basal conditions with moderate to high enrichment. It reflects low structure nature and moderate disturbances in the ecosystem due to human activities like various agricultural practices, household discharge of various chemicals and various industry wastes. Undisturbed indicated conditions highly structured stable and undisturbed nature of ecosystem with no human activities or any other disturbances. The system highly matured status of the ecosystem.

Biplot graph and PCA circle revealed the relationship between different variables and differentiated three different terrestrial habitats. Status of the various ecosystem conditions observed and compared on the basis of abundance and presence of different trophic groups of nematodes and their relationship with various diversity and ecological indices.

\section{CONCLUSION}

The present work was under taken to study the indicative assessment of nematode in differentiating the terrestrial habitats with respect to soil health using nematode community structure as a marker. Human disturbance can cause unintentional or intentional loss to ecosystems and environment, in particular industries and malpracticed agricultural activity where indiscriminate amount if inorganic fertilizers are used causes huge soil biodiversity degradation, which results in the loss of the structure and health of soil. The study contributes to an increase in the knowledge of diverse nematode community structure in different stressed and undisturbed soils and the changes that they undergo under the influence of different anthropogenic disturbances. These results may help the stakeholders to model and predict changes in biodiversity and species interactions with land use change. Further studies are required in the field of sampling methods, data analysis and use statistical tool for a better understating of different species of nematodes as bioindicators of soil health.

\section{ACKNOWLEDGEMENTS}

The financial assistance provided by UGC (University Grant Commission), MANF (Maulana Azad National Fellowship for Minority Students) and SERB (Science and Engineering Research Board), New Delhi are gratefully acknowledged.

\section{REFERENCES}

Ahmad, W. 1996. Plant parasitic nematodes of India: An identification Manual. Aligarh Muslim University, Aligarh, India: Department of Zoology, $347 \mathrm{pp}$.

Alloway, B.J. 1995. Soil pollution and land contamination. In: Pollution, causes, effects and control, 3rd Edition. Harrison, R.M. [Ed]. The Royal Society of Chemistry, Cambridge, UK. ISBN 0854045341

Andrássy I. 1956. The determination of volume and weight of nematodes. Acta Zoologica, 2: 1-15.

Andrássy, I. 1984. Klasse Nematoda (Ordnungen Monhysterida, Desmoscolecida, Araeolaimida, Chromadorida, Rhabditida). Stuttgart, Germany, Gustav Fischer Verlag, 509 pp.

Bakonyi, G., Nagy, P., Kovács-Láng, E., Kovács, E., Barabás, S., Répási, V. and Seres, A. 2007. Soil nematode community structure as affected by temperature and moisture in a temperate semiarid shrubland. Applied Soil Ecology, 37: 31-40.

Beier, S. and Traunspurger, W. 2001. Seasonal distribution of free-living nematodes in the Krähenbach, a ne-grained submountain carbonate stream in southwest Germany. Nematology, 5(1): 113-136.

Berkelmans, R., Ferris, H., Tenuta, M. and van Bruggen, A.H.C. (2003). Effects of long-term crop management on nematode trophic levels other than plant feedersdisappear after 1 year of disruptive soil management. Applied Soil Ecology, 23: 223-235.

Bokhorst, S., Berg, M.P. and Wardle, D. (2017). Microarthropod community responses to ecosystem retrogression in boreal forest. Soil Biology and Biochemistry, 110: 79-86. 10.1016/j.soilbio.2017.03.009.

Bongers T. 1990. The maturity index: an ecological measure of environmental disturbance based on nematode species composition. Oecologia, 83: 14-19.

Bongers, T. and Bongers, M. 1998. Functional diversity of nematodes. Applied Soil Ecology, 10: 239-251.

Bongers, T. and Ferris, H. 1999. Nematode community structure as a bioindicator in environmental monitoring. Trends in Ecology and Evolution, 14: 224-228. 
Bongers, T., van der Meulen, H. and Korthals, G. 1997. Inverse relationship between the nematode maturity index and plant parasite index under enriched nutrient conditions. Applied Soil Ecology, 6: 195-199.

Bongers T. 1999. The maturity index, the evolution of nematode life history traits, adaptive radiation and cp- scaling. Plant and Soil, 212: 13-22.

Čerevková, A. and Renčo, M. 2009. Soil nematode community changes associated with windfall and wildfi re in forest soil at the High Tatras National Park, Slovak Republic. Helminthologia, 46,123130. DOI: 10.2478/s11687-009-0024-9

Chapin, F.S., Schultz, E.D. and Mooney, H.A. 1992. Biodiversity and ecosystem processes. Trends in Ecology and Evolution, 7: 107-108.

Cobb, N.A. 1918. Estimating the nema population of the soil. U.S. Department of Agriculture. Agricultural Technical Circular of US Department of Agriculture, 1: 1-48.

Coleman, D.C. and Wall, D.H. 2015. Soil fauna: occurrence, biodiversity, and roles in ecosystem function. Fauna: the engine for microbial activity and transport. In: Paul, E.A. (Ed.), Soil Microbiology, Ecology and Biochemistry. Elsevier Inc., pp. 1-29.

Eder, R. and Kirchengast, M. 1982. The nematode-fauna (Nemathelminthes, Nematoda) of a polluted part of the river Mur (Styria, Austria). Nematologia Mediterranea, 10: 127- 134.

Elmer, W.H., Useman, S., Schneider, R.W., Marra, R.E., LaMondia, J.A. and Mendelssohn, I.A. (2013). Sudden vegetation dieback in Atlantic and Gulf Coast salt marshes. Plant Disease, 97: 436-445.

Ferris, H., Bongers, T. and De Goede, R.G.M. 2001. A framework for soil food web diagnostics: extension of nematode faunal analysis concept. Applied Soil Ecology, 18: 13-29.

Ferris, H. and Matute, M.M. 2003. Structural and functional succession in the nematode fauna of a soil food web. Applied Soil Ecology, 23: 93-110.

Ferris, H., Venette, R.C. and Scow, K.M. 2004. Soil management to enhance bacteriovore and fungivore nematode populations and their nitrogen mineralization function. Applied Soil Ecology, 25: 19-35.

Fiscus, D.A. and Neher, D.A. 2002. Distinguishing sensitivity of free-living soil nematode genera to physical and chemical disturbances. Ecological Applications, 12: 565-575.

Fließbach, A. and Mäder, P. 2000. Microbial biomass and size-density fractions differ between soils of organic and conventional agricultural systems. Soil Biology and Biochemistry, 32: 757-768.

Franco, A.L.C., Knox, M.A., Andriuzzi, W.S., Tomasel, C.M. de., Sala, O.E. and Wall, D.H 2017. Nematode exclusion and recovery in experimental soil microcosms. Soil Biology and Biochemistry, 108: 78-83.
Giola, P., Basso, B., Pruneddu, G., Giunta, F., Jones, J.W. 2012. Impact of manure and slurry applications on soil nitrate in a maize-triticale rotation: Field study and long-term simulation analysis. European Journal of Agronomy, 38: 4353.

Gomes, G.S., Huang, S.P. and Cares, J.E. 2003. Nematode Community, Trophic Structure and Population Fluctuation in Soybean Fields. Fitopatologia Brasileira, 28: 258-266.

Goodey, T. 1963. Soil and freshwater nematodes. $2^{\text {nd }}$ Edition. Rewritten by J. B. Goodey. London, Methuen and Co., 544 pp.

Háněl, L. and Čerevková, A. 2010. Species and genera of soil nematodes in forest ecosystems of the Vihorlat Protected Landscape Area, Slovakia. Helminthologia, 47: 123-135.

Háněl, L. 1995. Secondary successional stages of soil nematodes in cambisols of South Bohemia. Nematologica, 41: 197-218.

Háněl L. 1996. Comparison of soil nematode communities in three spruce forests at the Boubin Mount, Czech Republic. Biologia Bratislava, 51: 485-493.

Hánìl, L. 2001. Succession of soil nematodes in pine forests on coal-mining sands near Cottbus, Germany. Applied Soil Ecology, 16: 23-34.

Háněl, L. 1997. Vertical distribution of soil nematode diversity and abundance in a Central European oak forest. Acta Societatis Zoologicae Bohemoslovenica, 61: 97-112.

Háněl L. 2004. Colonization of chemical factory wastes by soil nematodes. Pedobiologia, 48, 373-381.

Hättenschwiler, S., Tiunov, A.V. and Scheu, S 2005. Biodiversity and litter decomposition in terrestrial ecosystems. Annual Review of Ecology, Evolution and Systematics, 36: 191218.

Hohberg K. 2003. Soil nematode fauna of affected mine sites: genera distribution, trophic structure and functional guilds. Applied Soil Ecology, 22: 113126.

$\mathrm{Hu}$, C. and Qi, Y.C. 2013. Effective microorganisms and compost favor nematodes in wheat crops. Agronomy for Sustainable Development, 33: 573579.

Hu, C., Hermann, G., Pen-Mouratov, S., Shore, L. and Steinberger, Y. 2011. Mammalian steroid hormones can reduce abundance and affect the sex ratio in a soil nematode community. Agriculture Ecosystems and Environment, 142: 275-279.

Hu. C., Wang, X.H. and Qi, Y.C. 2014. Characteristics of soil nematode communities under two different land use systems. Biological Agriculture and Horticulture: An International Journal for Sustainable Production Systems, 30: 119-130.

Ingham, R.E., Trofymow, J.A., Ingham, E.R. and Coleman, D.C. 1985. Interactions of bacteria, 
fungi, and their nematode grazers: Effects on nutrient cycling and plant growth. Ecological Monographs, 55: 119-140.

Jahan, R. and Tahseen, Q. 2018. "Diversity of Order Rhabditida in an Indian State" in Lambert Publishing House. LAP Lambert Academic Publishing, Germany, 164 pp.

Jairajpuri, M.S. and Ahmad, W. 1992. Dorylaimida: Free living, Predacious and plant parasitic nematodes. The Netherlands, E. J. Brill, Leiden, $458 \mathrm{pp}$.

Jairajpuri, M.S. and Khan, W.U. 1982. Predatory nematodes (Mononchida) with special reference to India. New Delhi Associated Publishing Co., $131 \mathrm{pp}$.

Khan, I., Zaman, M., Khan, M.J., Iqbal, M. and Babar, M.N. 2014. How to improve yield and quality of potatoes: effects of two rates of urea $\mathrm{N}$, urease inhibitor and Cytozyme nutritional program. Journal of Soil Science and Plant Nutrition, 14: 268-276.

Li, Q., Bao, X.L., Lu, C.Y., Zhang, X.K., Zhu, J.G., Jiang, Y. and Liang, W.J. 2012. Soil microbial food web responses to free-air ozone enrichment can depend on the ozone-tolerance of wheat cultivars. Soil Biology and Biochemistry, 47: 2735.

Li, X., Lewis, E.E., Liu, Q., Li, H., Bai, C. and Wang, Y. (2016b) Effects of long-term continuous cropping on soil nematode community and soil condition associated with replant problem in strawberry habitat. Scientific Reports, 6: 30466.

Liu, C.A., Li, F.R., Zhou, L.M., Zhang, R.H., Jia, Y., Lin, S.L., Wang, L.J., Siddique, K.H.M. and Li, F.M. 2013. Effect of organic manure and fertilizer on soil water and crop yields in newly-built terraces with loess soils in a semi-arid environment. Agricultural Water Management, 117: 123-132.

Neher, D.A. 2001. Nematode communities as ecological indicators of agroecosystem health. In: Gliessman, S.R. (Ed.), Agroecosystem sustainability: Developing practical strategies. CRC/Lewis Press, Boca Raton, FL, pp.105-120.

Neher, D. A. 2010. Ecology of plant and free-living nematodes in natural and agricultural soil. Annual Review of Phytopathology, 48: 371-394.

Neher, D.A. and Campbell, C.L. 1994. Nematode communities and microbial biomass in soils with annual and perennial crops. Applied Soil Ecology, 1: $17-28$.

Norton D.C. 1978. Ecology of plant parasitic nematodes. John Wiley and Sons, New York, USA, 268 pp.

Oloyede, F.M. 2012. Growth, yield and antioxidant profile of pumpkin (Cucurbita epo L.) leafy vegetable as affected by NPK compound fertilizer. Journal of Soil Science and Plant Nutrition, 12: 379-387.
Ou, W., Liang, W., Jiang, Y., Li, Q. and Wen, D. 2005. Vertical distribution of soil nematodes under different land use types in aquic brown soil. Pedobiology, 49: 139-148.

Park, S.J., Taylor, R. and Grewal, P.S. 2013. Spatial organization of soil nematode communities in urban landscapes: Taylor's Power Law reveals life strategy characteristics. Applied Soil Ecology, 64: 214-222.

Pate, E., Ndiaye-Faye, N., Thioulouse, J., Villenave, C., Bongers, T., Cadet, P. and Debouzie, D. 2000. Successional trend in characteristics of soil nematode communities in cropped and fallow lands in Senegal (Sonkorong). Applied Soil Ecology, 14: 5-15.

Pattison T., Badlock K., Armour J., Moody P., Rasiah V., Cobbon J., Steward L., Guilino L. and Linda S. 2004. Using nematodes as bio-indicators for soil health in bananas "Super Soil." Proceedings of the International Soil Science Conference, 5-9 December, Sydney, Australia, 1-9 pp.

Pen-Mouratov, S., Shukurov, N. and Steinberger Y. 2010. Soil free-living nematodes as indicators of both industrial pollution and livestock activity in Central Asia. Ecological Indicators, 10: 955-967.

Ruess, L. 2003. Nematode soil faunal analysis of decomposition pathways in different ecosystems. Nematology, 5(2): 179-181.

Siddiqi, M.R. 1986. Tylenchida: Parasites of Plants and Insects. Farnham Royal, UK: Commonwealth Agriculture Bureaux, 645 pp.

Sithole N.J., Magwazaa, L.S. and Mafongoya, P.L. 2016. Conservation agriculture and its impact on soil quality and maize yield: A South African perspective. Soil and Tillage Research, 162: 5567.

Sohlenius, B., Wasilewska, L. (1984). Influence of irrigation and fertilization on the nematode community in a Swedish pine forest soil. Journal of Applied Ecology, 32: 327- 342. DOI: $10.2307 / 2403057$

Sohlenius, B. 2002. Influence of clear-cutting and forest age on the nematode fauna in a Swedish pine forest soil. Applied Soil Ecology, 19: 261-277. DOI: 10.1016/S0929-1393(02)00003-3

Sohlenius, B. 1980. Abundance, biomass and contribution to energy flow by soil nematodes in terrestrial ecosystems. Oikos, 34: 186-194.

Stone, D., Costa, D., Daniell, T.J., Mitchell, S.M., Topp, C.F.E. and Griffiths, B.S. 2016a. Using nematode communities to test a European scale soil biological monitoring programme for policy development. Applied Soil Ecology, 97: 78-85.

Tahseen, Q., Liang, A. and Hussain, A. 2011. Evaluating the indicative role of soil nematode assemblages and food web indices in two wetlands. Nematologica Mediterranea, 39: 133-140.

Tarazona, J.V., Fernández M.D. and Vega, M.M. 2005. "Regulation of Contaminated Soils in Spain e a 
New Legal Instrument,". Journal of Soils Sediments, 5(3): 121-124.

Thomas, S.H. 1978. Population densities of nematodes under seven tillage regimes. Journal of Nematology, 10: 24-27.

Thornton, C.W. and Matlack, G.R. (2002) Long-term disturbances effects in the nematode communities of South Mississippi woodlands. Journal of Nematology, 34: 88-97.

Tomar, V.V.S. and Ahmad, W. 2009. Food web diagnostics and functional diversity of soil inhabiting nematodes in natural woodland. Helminthologia, 46: 183-189.

Ugarte, C.M., Zaborski, E.R. and Wander, M.M. 2013. Nematode indicators as integrative measures of soil condition in organic cropping systems. Soil Biology and Biochemistry, 64: 103-113.

Wall, J.W., Skene, K.R. and Neilson, R. 2002. Nematode community and trophic structure during sand dune succession. Biology and Fertility of Soils, 35: 293-301.

Wall, J.W., Skene, K.R. and Neilson, R. 2002. Nematode community and trophic structure along 10 a sand dune succession. Biology and Fertility of Soils, 35: 293-301, doi:10.1007/s00374-002-0478-0.

Wang, K-H., McSorley, R. and Gallaher, R.N. 2009. Can nematode community indices elucidate plant health conditions? Journal of Nematology, 41: 392.

Wasilewska, L. 1979. The structure and function of soil nematode communities in natural ecosystems and agrocenoses. Polish Ecological Studies, 5: 97145 .

Wasilewska, L. 1994. The effect of age of meadows on succession and diversity in soil nematode communities. Pedobiologia, 38: 1-11.
Yeates, G.W. 2007. Abundance, diversity, and resilience of nematode assemblage in forest soils. Canadian Journal of Forest Research, 37: 216-225.

Yeates G.W. 1998. Feeding in free-living soil nematodes: a functional approach. In: Perry R.N. and Wright D.J. (Eds.), Physiology and Biochemistry of Free-Living and Plant Parasitic nematodes. CAB International, Wallingford, UK, pp. 245-269.

Yeates, G.W. 2003. Nematodes as soil indicators: functional and biodiversity aspects. Biology and Fertility of Soils, 37: 199-210.

Yeates, G.W. and Bongers, T. 1999. Nematode diversity in agro-ecosystems. Agriculture, Ecosystems and Environment, 74: 113-135.

Yeates, G.W. and Bird, A.F. (1994) Some observations on the influence of the agricultural practices on the nematode faunae of some South Australian soils. Fundamental and Applied Nematology, 17: 133-145.

Yeates, G.W., Bongers, T., De Goede, R.G.M., Freckman, D.W. and Georgieva, S.S. 1993. Feeding habits in soil nematode families and genera-an outline for soil ecologists. Journal of Nematology, 25: 315-331.

Yeates, G.W., Hawke, M.F., Rijkse, W.C. 2000. Changes in soil fauna and soil conditions under Pinus radiata agroforestry regimes during a 25year tree rotation. Biology and Fertility of Soils, 31: 391-406. DOI: 10.1007/s003749900186

Zhang, X.K., Li, Q., Zhu, A.N., Liang, W.J., Zhang J.B., and Steinberger, Y. 2012. Effects of tillage and residue management on soil nematode communities in North China. Ecological Indicators, 13: 75-81.

Citation: Asif, M., Jahan, R. and Mahboob, M. 2021.Biological indicative assessment of nematodes in evaluating different terrestrial habitats. International Journal of Agricultural and Applied Sciences, 2(1):91-109. https://doi.org/10.52804/ijaas2021.2110

Copyright: (C) Asif et.al 2021. Creative Commons Attribution 4.0 International License. IJAAS allows unrestricted use, reproduction, and distribution of this article in any medium by providing adequate credit to the author(s) and the source of publication. 